\title{
Crystal Chemistry and Geochronology of Thorium-Rich Monazite from Kovela Granitic Complex, Southern Finland
}

\author{
Thair Al-Ani'1, Pentti Hölttä1, Sari Grönholm¹, Lassi Pakkanen1, Nadhir Al-Ansari² \\ ${ }^{1}$ Geological Survey of Finland (GTK), Vuorimiehentie 5, Espoo, Finland \\ ${ }^{2}$ Lulea University of Technology, Lulea, Sweden \\ Email: thair.alani@gtk.fi,pentti.holtta@gtk.fi,sari.gronholm@gtk.fi, lassi.pakkanen@gtk.fi, nadhir.alansari@ltu.se
}

How to cite this paper: Al-Ani, T., Hölttä, P., Grönholm, S., Pakkanen, L. and Al-Ansari, N. (2019) Crystal Chemistry and Geochronology of Thorium-Rich Monazite from Kovela Granitic Complex, Southern Finland. Natural Resources, 10, 230-269. https://doi.org/10.4236/nr.2019.106016

Received: May 25, 2019

Accepted: June 24, 2019

Published: June 27, 2019

Copyright $\odot 2019$ by author(s) and Scientific Research Publishing Inc. This work is licensed under the Creative Commons Attribution International License (CC BY 4.0).

http://creativecommons.org/licenses/by/4.0/

\begin{abstract}
Abundant porphyritic granites, including Grt-bearing and Bt-bearing porphyritic granites, and porphyritic potash-feldspar granite (trondhjemite-granitic composition) are widely distributed within the Kovela granitic complex Southern Finland, which associated with monazite-bearing dikes (strong trondhjemite composition). The investigated monazite-bearing dikes are dominated by a quartz $+\mathrm{K}$-feldspar + plagioclase + biotite + garnet + monazite assemblage. The monazite forms complexly zoned subhedral to euhedral crystals variable in size (100 - $1500 \mu \mathrm{m}$ in diameter) characterized by high Th content. The chemical zoning characterised as: 1) concentric, 2) patchy, and 3) intergrowth-like. Textural evidence suggests that these accessory minerals crystallized at an early magmatic stage, as they are commonly associated with clusters of the observed variations in their chemical composition are largely explained by the huttonite exchange $\left[(\mathrm{Th}, \mathrm{U})^{4+}+\mathrm{Si}^{4+} \leftrightharpoons \mathrm{REE}^{3+}+\mathrm{P}^{5+}\right]$, and subordinately by the cheralite exchange $\left[(\mathrm{Th}, \mathrm{U})^{4+}+\mathrm{Ca}^{2+} \leftrightharpoons 2 \mathrm{REE}^{3+}\right]$ with proportions of huttonite $\left(\mathrm{ThSiO}_{4}\right)$ and cheralite $\left[\mathrm{CaTh}\left(\mathrm{PO}_{4}\right)_{2}\right]$ up to $20.4 \%$ and $9.8 \%$, respectively. Textural evidence suggests that these monazites and associated Th-rich minerals (huttonite/thorite) crystallized at an early magmatic stage, rather than metamorphic origin. The total lanthanide and actinide contents in monazite and host dikes are strongly correlated. Mineral compositions applied to calculate $\mathrm{P}-\mathrm{T}$ crystallization conditions using different approaches reveal a temperature range of $700^{\circ} \mathrm{C}-820^{\circ} \mathrm{C}$ and pressure $3-6 \mathrm{kbars}$ for the garnet-biotite geothermometry. P-T pseudo-section analyses calculated using THERMOCALC software for the bulk compositions of suitable rock types, constrain the PT conditions of garnet growth equilibration within the range of 5 - 6 kbars and $760^{\circ} \mathrm{C}-770^{\circ} \mathrm{C}$ respectively. Empirical calculations and
\end{abstract}


pseudo-section approaches indicate a clockwise P-T path for the rocks of the studied area. ${ }^{207} \mathrm{~Pb} /{ }^{206} \mathrm{~Pb}$ dating of monazite by LA-MC-ICPMS revealed a recrystallization period at around $1860-1840 \mathrm{Ma}$. These ages are related to the tectonic-thermal event associated with the intense crustal melting and intra-orogenic intrusions, constraining the youngest time limit for metamorphic processes in the Kovela granitic complex.

\section{Keywords}

Monazite Growth and Recrystallization, Monazite Dating, P-T Path, Huttonite, Kovela Granitic Complex, Finland

\section{Introduction}

The Kovela granitic complex in Finland is part of a series of metamorphic events, which have to be fully understood [1] [2] [3]. The crystal chemistry of the monazite mineral textures was used better to understand the geochronology of this system. The Kovela granitic complex is characterized by well-developed zoned structure consisting of several generations of bedrocks: porphyritic $\mathrm{K}$-feldspar granite and small granodiorite bodies at the center, pyroxene gneiss at the margin and garnet-cordierite gneiss as well marginal pegmatite along the outer contact of the complex (Figure 1(a)). Strongly radioactive (monazite-bearing dikes) and weakly radioactive pegmatite dikes are abundant in the central zone and also present in lesser amounts in the surrounding country-rocks. Most of the dikes run roughly in NW-SE direction, and are named according to their location: the $\mathrm{S}$ dikes $(5-10 \mathrm{~m} \times 60 \mathrm{~m})$ and the $\mathrm{N}$ dikes $(10 \mathrm{~m}$ $\times 70 \mathrm{~m}$ ), both less than 10 meters wide. The $S$ dikes are most radioactive in the complex (Figure 1(a)). The monazite-bearing dikes belong to the late orogenic granites on the basis of $\mathrm{U}-\mathrm{Pb}$ analysis of the Karhukoski monazite, $1801 \mathrm{Ma} \pm 20$ [4].

The geological setting was understood, were petrography characterization methods used to examine the crystal chemistry isotope relationships. This paper presents the results of whole-rock analyses of the monazite-bearing dikes, details of their mineral assemblages, their spatial zonal variation, and micro-analytical study of monazite hosted within monazite-bearing dikes and porphyritic biotite granite from the Kovela granitic complex, southeastern Finland. The monazite grains display complex textural features and chemical zoning patterns that suggest partial crystallization during the high-temperature, low-pressure metamorphic conditions occurred during the Paleoproterozoic Svecofennian orogeny $(\sim 1.83 \mathrm{Ga})$. This metamorphic event has been very well bracketed in terms of ages by previous zircon isotopic age dating and so enable an informed interpretation of $\mathrm{U}-\mathrm{Pb}$ ages obtained from monazite. Internal zoning patterns and ${ }^{207} \mathrm{~Pb} /{ }^{206} \mathrm{~Pb},{ }^{206} \mathrm{~Pb} /{ }^{238} \mathrm{U}$ and ${ }^{207} \mathrm{~Pb} /{ }^{235} \mathrm{U}$ LA-ICPMS isotopic dating of coexisting monazite grains are combined with compositional information in order to provide 

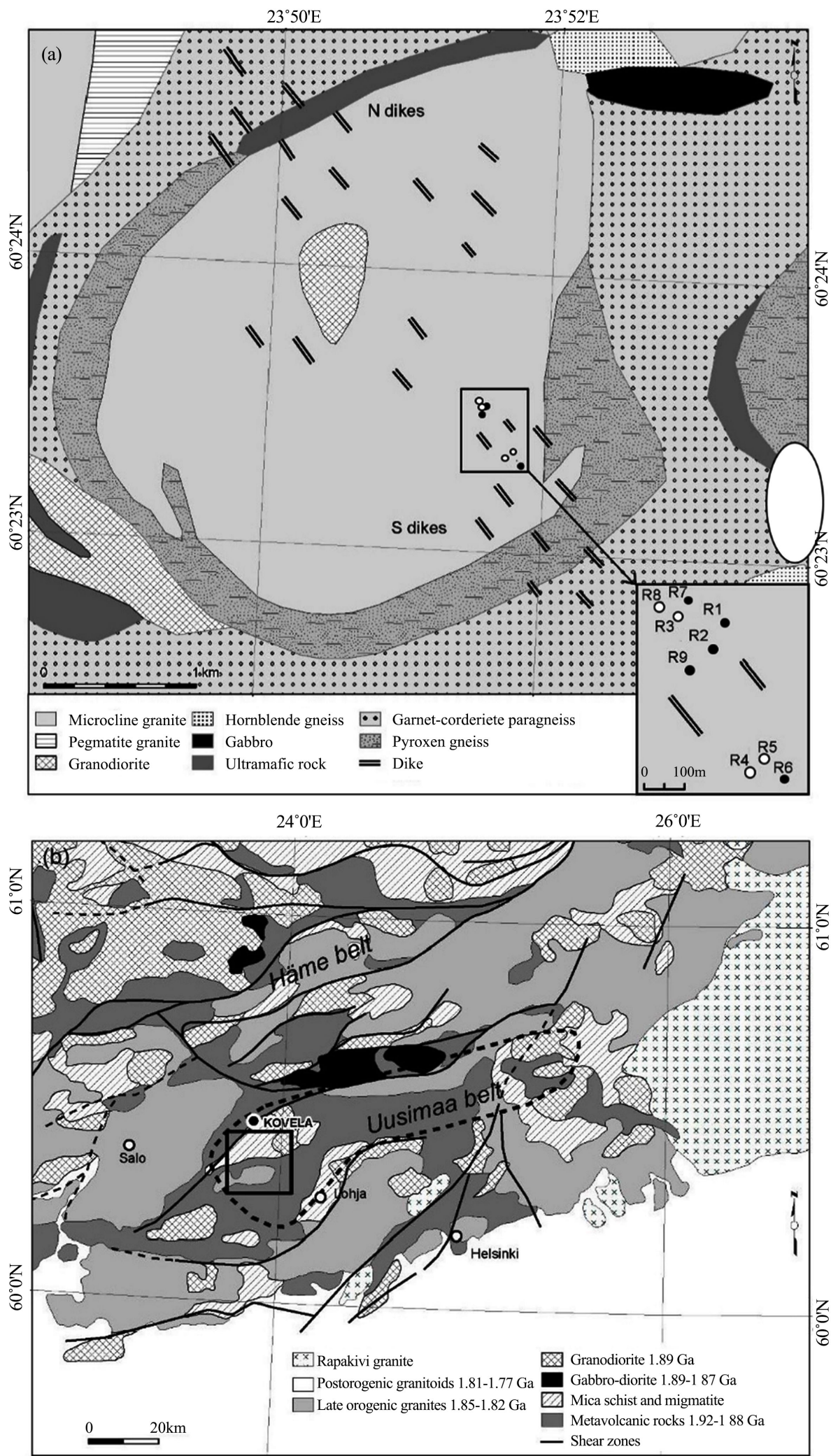

Figure 1. (a) Simplified geological map of Fennoscandian shield based on [8]. (b) Map showing the major lithological units of the Kovela granitic complex and the location of the drilled boreholes intersecting the monazite-bearing dikes as indicated with circles, from which the black ones intersecting the porphyritic granite. Coordination is based on Finnish National System ETRS-TM35FIN. 
further insight into the temporal evolution of this poly-cyclic high grade metamorphic terrane. Monazite grains record growth during crystallization of partial melts during an early metamorphic event followed by partial resetting during subsequent metamorphism and deformation.

\section{Geological Setting}

The Kovela granitic complex occurred in western-Uusimaa belt $(\sim 1.83 \mathrm{Ga})$, southern Finland during the later stages of the Paleoproterozoic Svecofennian orogeny [2]. The Palaeoproterozoic Uusimaa Belt in southwestern Finland is part of the central Fennoscandian Shield (Figure 1(b)). The Uusimaa belt consists of metabasic rocks, metagreywackes, metavolcanic rocks of felsic composition (leptites) and syngenetic gabbro-tonalite bodies, is a westerly striking portion of the early Proterozoic. (1.90 - 1.88 Ga) Svecofennian Belt [3] [4] [5] [6], and late Svecofennian $1.85-1.80 \mathrm{Ga}$ granites derived from melting of the crust [7] [8] [9]. High-temperature, low-pressure type metamorphism, locally reaching granulite facies, characterize the late Svecofennian events [10]. The peak metamorphic conditions in the Uusimaa Belt are estimated at $\mathrm{T}=750^{\circ} \mathrm{C}-800^{\circ} \mathrm{C}$ and $\mathrm{P}=4-5 \mathrm{kbars}$, associated with crustal melting, occurred during $1.83-1.82$ $\mathrm{Ga}$ [11]. The high heat flow combined with the related deformation during late Svecofennian events effectively overprinted the early structures in most places. Crustal shortening occurred within a transpressional tectonic regime [12], where the early Svecofennian structures were first transposed predominantly into upright folds with E-W trending axial surfaces reflecting -N-S contraction [2]. At the same time, some shear zones were generated [13] [14], although the majority of shear zones were formed later when the last episodes of crustal shortening led to strain localization into a network of subvertical shear zones [15] [16]. The area was then cooled down to $700^{\circ} \mathrm{C}-600^{\circ} \mathrm{C}$ at $1.81-1.79 \mathrm{Ga}$ according to Sm-Nd garnet-whole rock data [16]. The Kovela granitic complex which forms a part of Uusimaa belt was affected by multiple stages of deformation and regional metamorphism during the Svecofennian orogeny, peaking at early Svecofennian cycle at ca. $1.90-1.88 \mathrm{Ga}$, and a late Svecofennian cycle at ca. 1.85 $1.80 \mathrm{Ga}$, separated by an extensional episode between ca. 1.86 and $1.84 \mathrm{Ga}$. [8] [13].

\section{Materials and Methods}

Thin sections were prepared from fifteen samples, 10 of which were selected for further studies. Petrographic observations were made by using a combination of reflected and transmitted light microscopy. High-resolution imaging of individual monazite grains from monazite-bearing dikes was performed by using a high-resolution scanning electron microscope (JEOL JSM 5900 LV) in order to characterise internal zoning or other heterogeneities in individual grains of monazite. Quantitative analyses of monazite and $\mathrm{ThSiO}_{4}$, as well as element maps, were performed using the Cameca SX100 electron microprobe at the laboratory 
of the Geological Survey of Finland (GTK). For element mapping of monazite, the following conditions were obtained: beam current $60 \mathrm{nA}$, step size $0.5 \mathrm{~mm}$, beam diameter $1 \mu \mathrm{m}$. Backscattered electron (BSE) images were recorded with scanning electron microscope (SEM) and electron probe microanalysis (EPMA). Element mapping of YLa (on TAP crystal), CeLa (on LLIF crystal), LaLa (on LLIF crystal), UMb (on PET crystal) and ThMa (on LPET crystal) were made in stage scan mode using $20 \mathrm{kV}$ accelerating voltage, $100 \mathrm{nA}$ beam current and a dwell time of 100 - $200 \mathrm{~ms}$.

Mineral analyses were assisted by appropriate back-scattered electron (BSE) images to ensure that representative and homogeneous probe points were selected for analysis. Analytical spots were performed avoiding micro-fissures, where $U$ could be redistributed. Detailed EPMA analytical methods are presented in Supplementary data Appendix 1 and compositional data of the selected monazite-(Ce) and the $\mathrm{ThSiO}_{4}$ grains are given in Supplementary data Tables 1-3.

Whole-rock major oxides were analyzed by using X-ray fluorescence (XRF) spectrometry and trace elements including rare earth elements (REE) data were acquired by Inductively Coupled Plasma-Mass Spectrometry (ICP-MS) at the at Labtium laboratories, Finland. The results are presented in Supplementary data Table 4.

The U-Pb isotopic dating was performed using a LA-MC-ICPMs AttoM laser ablation system that at the laboratory of the Geological Survey of Finland (GTK). The monazite dating was performed in situ on three polished thin sections after BSE and CL image observations. Details of the analytical methods for three selected samples and conditions are summarized in Supplementary data Appendix 1. The results of the U-Pb dating for three selected samples are presented in Supplementary data Table 5.

The P-T conditions for crystallization of garnets have been calculated using the garnet-biotite thermometer of [17] in combination with the linearized calibrations of the garnet-plagioclase-biotite-quartz barometer $\mathrm{P}(\mathrm{GBPQ})_{\mathrm{Wu}}$ calibrated by $\mathrm{Wu}$ et al. [57]. Tentative calculations by other [18] [19] yielded no substantially different results. The mineral compositions that were used for thermobarometry and for plotting garnet commotional isopleths are listed in Supplementary data Table 6. The bulk rock compositions were then used to calculate an accurate pressure-temperature phase diagram for the alteration assemblage of interest in the model chemical system $\mathrm{Na}_{2} \mathrm{O}-\mathrm{CaO}-\mathrm{MgO}-\mathrm{FeO}-\mathrm{Al}_{2} \mathrm{O}_{3}-\mathrm{SiO}_{2}-\mathrm{H}_{2} \mathrm{O}$. The software package PERPLEX [20] [21] [22] [23] was used to calculate a mineral stability pressure-temperature phase diagram for the rocks types distributed within the Kovela granitic complex.

\section{Petrography and Mineralogy}

The Kovela granitic complex consists of various porphyritic granites and show crosscutting contact with monazite-bearing dikes. On the basis of their texture 
and mineral contents, the porphyritic granites and associated dikes including: 1) Grt-bearing porphyritic granite; 2) Bt-bearing porphyritic granite; 3) porphyritic potash-feldspar (microcline) granite; 4) monazite-bearing dikes. A general petrographic description of these rocks has been described in detail elsewhere [24].

The Grt-bearing porphyritic granite mainly consists of garnet (Grt) + biotite $(\mathrm{Bt})+$ plagioclase $(\mathrm{Pl})+\mathrm{K}$-feldspar $(\mathrm{Kfs})+$ quartz $(\mathrm{Qz}) \pm$ sillimenite $(\mathrm{Sil}) \pm$ corderite (Crd) that occur as irregular layers, or block in Kovela granitic complex. Garnet typically occurs as rounded subhedral red-brown crystals; rare euhedral grains are also present. Grain sizes range from 2 to $12 \mathrm{~mm}$, with an average grain size of $8 \mathrm{~mm}$. The garnet crystals contain inclusions of quartz, plagioclase, biotite, zircon, and monazite; usually, garnets are highly fragmented with numerous fractures filled by chlorite or retrograde biotite (Figure 2(a) and Figure 2(b)). These textural evidences provide criteria for the recognition of peritectic garnet with a magmatic origin in the host pluton. The macroscopic foliation is defined by aligned sillimanite and $1-2 \mathrm{~mm}$ long brown biotite, and both of these minerals surrounded garnet phenocryst (Figure 2(a)).

The Bt-bearing porphyritic granite samples are mainly comprised of $\mathrm{K}$-feldspar $(\mathrm{Kfs})+$ plagioclase $(\mathrm{Pl})+$ quartz $(\mathrm{Qz})$, with biotite $(\mathrm{Bt})$, and with accessory sillimanite. The core of plagioclase is strongly altered to sericite and locally to muscovite and calcite. Biotite occurs as brown flakes, 2 - $4 \mathrm{~mm}$ in length, with a preferred orientation, but may be kinked due to deformation, and is mostly altered to chlorite and/or sericite. The optical features of biotite are consistent with matrix biotite or like lenses and aggregates (Figure 2(c)).

The porphyritic K-feldspar (microcline) granite is characterized by highly perthitic alkali feldspar, large quartz grains, plagioclase (forms sub- to anhedral grains), elongated biotite and needle-like sillimanite grains (Figure 2(d)). Plagioclase occurs as larger ( 0.5 to $5 \mathrm{~mm}$ ) crystals that have euhedral to subhedral and few sericite aggregates occur along cleavages and at the edges of grains (Figure 2(b) and Figure 2(c)). The presence of plagioclase showing intragranular fractures filled by late magmatic minerals such as quartz and K-feldspar is also recognized. This possibly represents microfractures developed in the presence of late-stage melt (Figure 2(c) and Figure 2(d)). Alkali feldspars occur as megacryst crystals (10 to $15 \mathrm{~mm}$ ) perthitic microcline, showing undulate extinction and weak deformation (Figure 2(a) and Figure 2(c)).

The investigated samples of monazite-bearing dikes are tonalitic and trondhjemitic in compositions and dominated by a quartz $+\mathrm{K}$-feldspar + plagioclase + garnet + biotite + monazite assemblage with accessories of xenotime, thorite zircon. Monazite-(Ce) forms platy tabular, elongated prismatic crystals, euhedral to subhedral in shape, with colors that range from honey-yellow, green, violet and brown (Figure 2(e) and Figure 2(f)). Grains range in size from $0.1 \times 0.05$ $\mathrm{mm}$ to $4.5 \times 1.0 \mathrm{~mm}$. The monazite crystals show a magmatic texture and they are mostly enclosed by quartz and K-feldspar (Figure 2(e) and Figure 2(f)). 

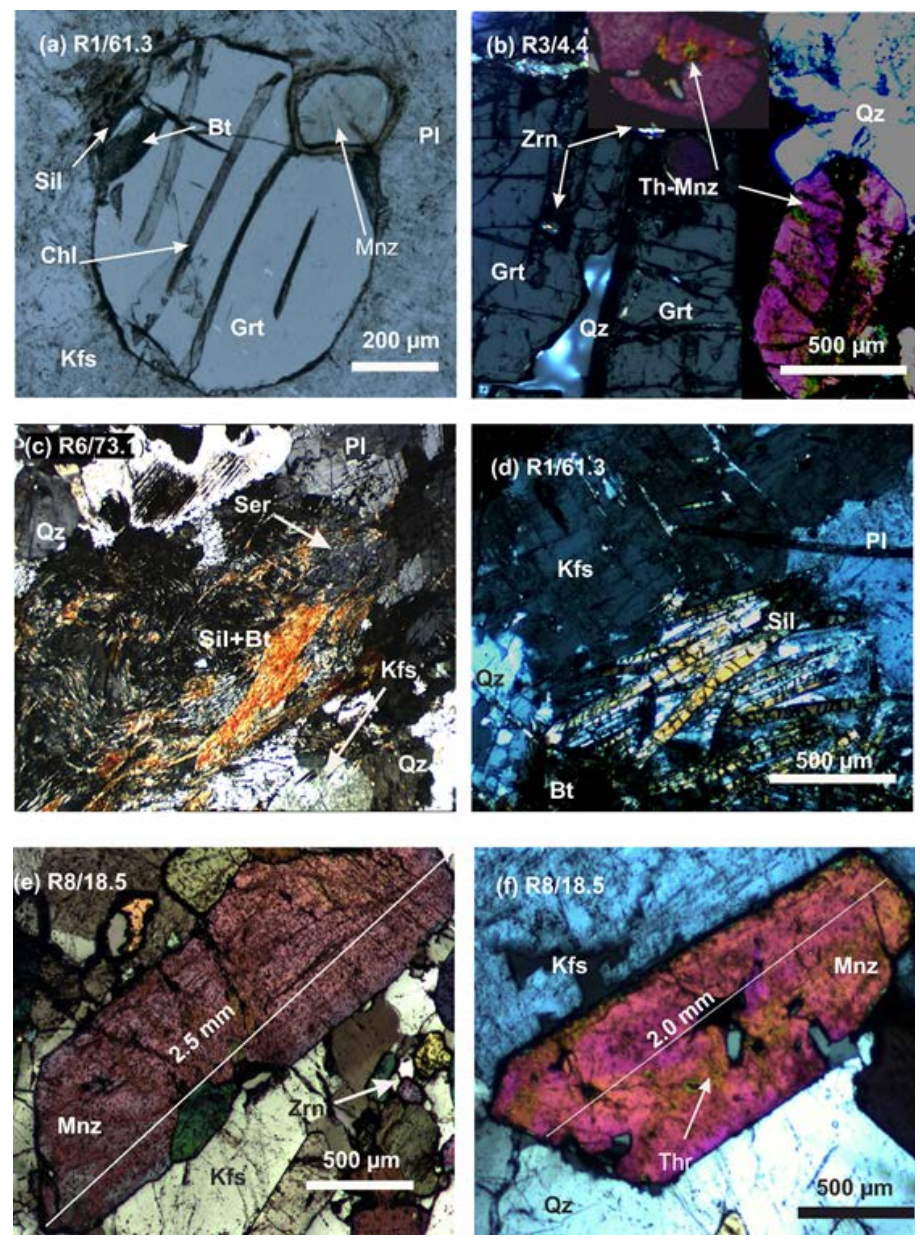

Figure 2. Microphotographs of mineral assemblages in the studied porphyritic granite and monazite-bearing dikes (a) coarse K-feldspar (Kfs) and quartz (Qz) grains in contact with needle like sillimanite (Sil), (b) porphyritic granite type showing garnet (Grt) porphyroblast associated with monazite crystals (Mnz), (c) garnet (Grt) porphyroblast surrounded by sillimanite (fibrolite) and biotite (Bt), (d) cordierite (Crd) in contact with quartz, sillimanite and biotite, (e-f) Monazite-(Ce) forms platy tabular, elongated prismatic crystals, euhedral in shape, and in contact with feldspar and quartz from monazite-bearing dikes.

or occur in contact with garnet (Figure 2(b)). Thorite appears as inclusions within monazite and zircon (Figure 2(a) and Figure 2(b)), displaying bright yellow and green interference colors. Two types of zircons were found: 1) coarse-grained zircon crystals ranging in size from 100 to $400 \mu \mathrm{m}$, have mainly subhedral, and euhedral prismatic shapes, although some zircon grains show concentric zoning in BSE images (Figure 2(a)); and 2) smaller $(<50 \mu \mathrm{m})$, rounded to subhedral grains that occur as inclusions in garnet and monazite (Figure 2(c)). The porphyritic biotite granite consists of euhedral to subhedral alkali feldspar and plagioclase megacrysts with fine-grained aplitic groundmass. Plagioclase is usually normally zoned, and has been variably sericitized. Biotite occurs as brown flakes, $2-4 \mathrm{~mm}$ in length, with a preferred orientation, but may be kinked due to deformation, and is mostly altered to chlorite and/or sericite. 
At some samples, biotite as lepido aggregations forms weak foliations and weak gneissic structures (Figure 2(c) and Figure 2(d)). Accessory minerals include zircon, xenotime and thorite, which have appeared as inclusions within monazite or garnet (Figure 2(b) Figure 2(c) Figure 2(e) and Figure 2(f)).

\subsection{Monazite Zoning and Element Mapping}

A remarkable feature of the monazites grains from monazite-bearing dikes in Kovela granitic complex show large monazite crystals $(>200 \mu \mathrm{m})$ with complex zoning that express variations in chemical composition (Figures 3(a)-(h)); only a few exhibit homogenous or just weakly zoned (Figure 3(i)). Similar zonation in monazites was also observed in this study, such as concentric, sector and intergrowth-like zonation patterns.
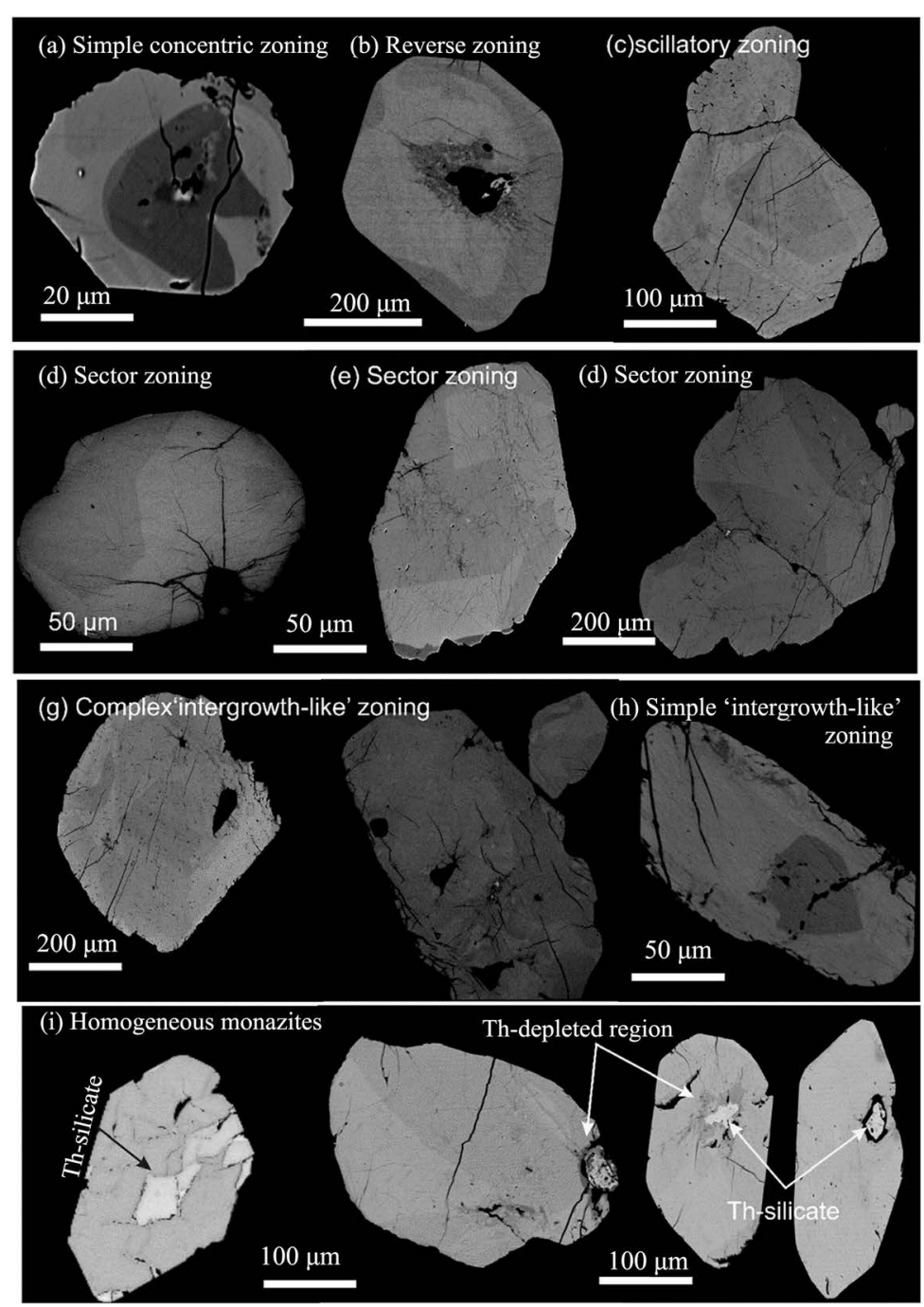

Figure 3. BSE images showing the representative textures of monazite types from monazite-bearing dikes; (a-c) concentric, oscillatory growth zoning, (d-f) patchy, mosaic or irregular zoning, (g-h) complex and simple intergrowth-like zoning, (i) thorium-silicate minerals occurring as inclusions along monazite crystal rims or as disseminated crystals within homogenous monazite grains. 
Type-I monazite forms subhedral to euhedral crystals $(200-500 \mu \mathrm{m}$ in diameter), with concentric simple zoning of characterized by BSE-darker cores (lower density phase) grading to BSE-bright rims that embay cores along curved, lobate fronts (Figure 3(a)). Monazite grain from the R3/2.35_Mnz 4 shows higher BSE brightness, which correlates with significant Th-enrichment in these rim domains and is typically slightly poorer in LREE and $\mathrm{Y}$ in comparison to cores and inclusions (Figure 4(a)). Reverse zoning pattern where the bright core has a high Th content and the dark rim has relatively low Th content is also observed (Figure 3(b)). Several grains have weak oscillatory zoning (Figure 3(c), which is typical for monazite grown from melt-related monazite [25], though their trace element composition is similar to other grains (Figures 3-5). Monazite

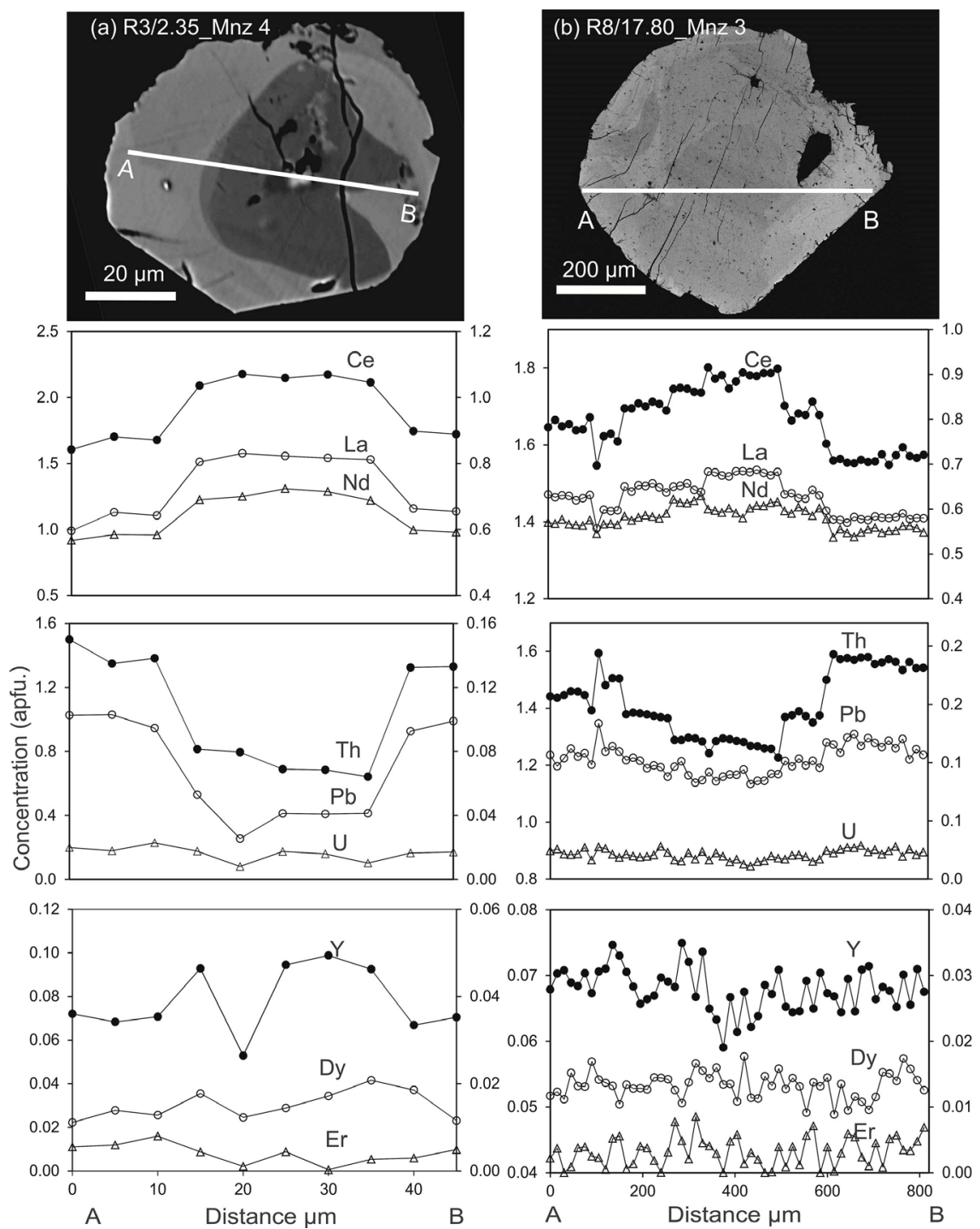

Figure 4. Analytical traverse of chemical profiles for a single monazite grain; (a, b) BSE images of simple zoning monazite grain R3/2.35_Mnz 4 and oscillatory zoning monazite grain R8/17.80_Mnz 3 from monazite-bearing dikes, displaying the selected positions for analytical traverses. The boxplots below show elemental concentrations vs. distance plot, displaying the variation along the traverse for each measured element. 

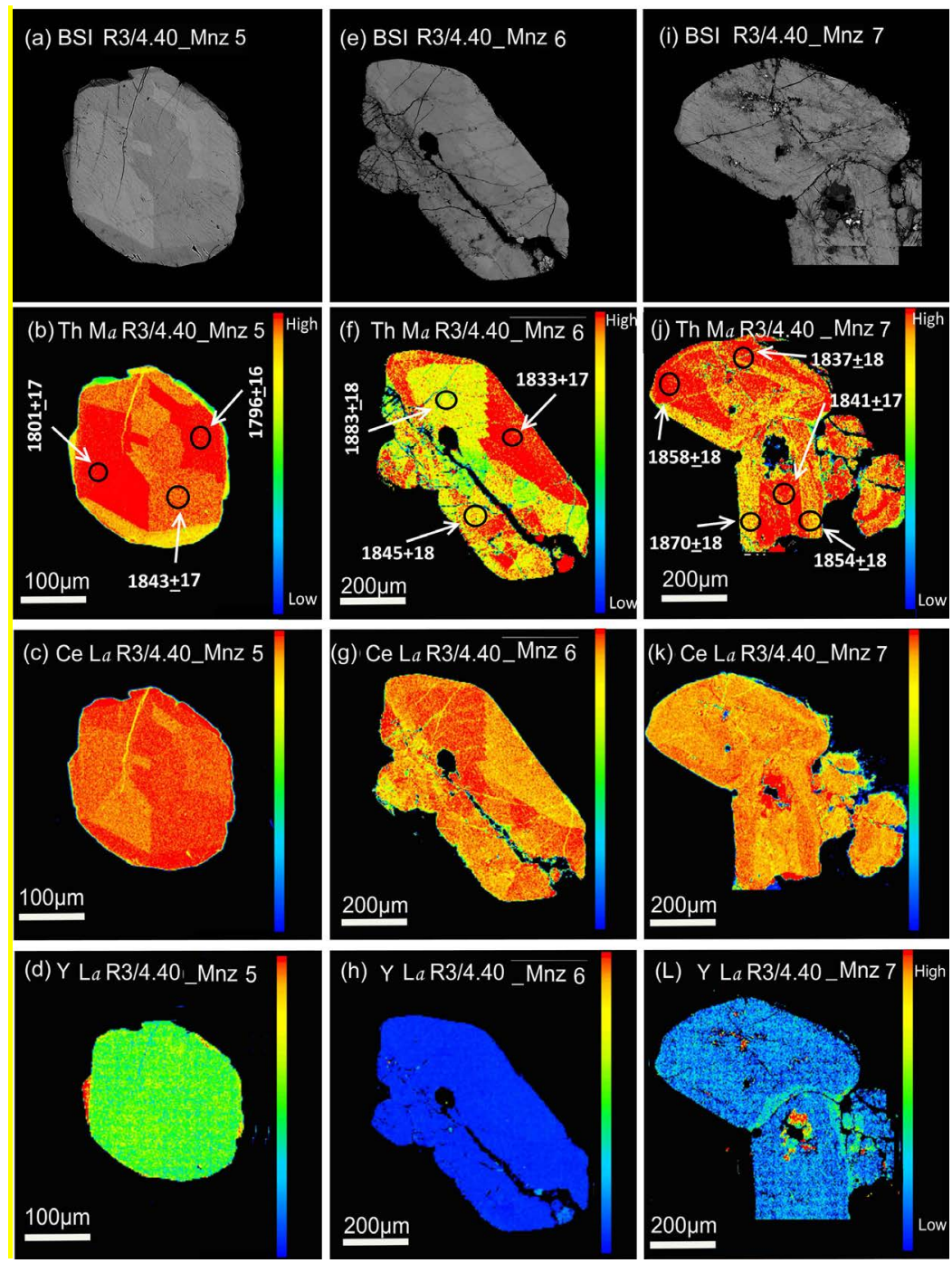

Figure 5. Chemical mapping of three monazite grains from the R3/4.4 monazite-bearing dikes from the Kovela granitic complex (warm colours indicate higher concentrations; cold colours indicate lower concentrations); (a-d) BSE image and Th-Ce-Y X-ray maps for oscillatory zoning monazite R3/4.40 Mnz 5; (e-h) BSE image and Th-Ce-Y X-ray maps for sector-zoning monazite R3/4.40 Mnz 6, monazite with a high-Th rim; (i-L) BSE image and Th-Ce-Y X-ray maps for sector-zoning monazite R3/4.40 Mnz 7, monazite with a low-Th rim.

grains from the R8/17.80 have oscillatory zoning with a LREE (Ce)-rich core surrounded by several overgrowths with a composition grading toward a Th-Si-rich boundary (Figure 3(c)). EPMA traverse for REE, $\mathrm{Y}, \mathrm{Th}, \mathrm{U}$ and $\mathrm{Pb}$ from light to dark patches in single monazite grain R8/17.80_Mnz 3 confirm these bulk observations. $\mathrm{Ce}, \mathrm{La}$ and $\mathrm{Nd}$ significantly increase, and $\mathrm{Th}, \mathrm{U}$ and $\mathrm{Pb}$ decrease in dark patches from dark domains in the monazite cores towards bright domains in the rims (Figure 4(b)). Y and HREE profiles are also correlated with LREE profiles, but sometimes appeared as a zig-zag pattern.

Type-II monazite has sector-zoning, characterized by irregularly shaped, subequant zones with distinct backscattered intensity (composition) associated with 
embayment, fractures, and inclusions (Figure $3(d)$ ). The sector zones texturally appear to overprint pre-existing zoning. However, the contrasts between the domains are often sharp and the domain boundaries tend to have a wedge-shaped (Figures 3(d)-(f)).

Type-III monazite with "intergrowth-like" zonation displays an internal microstructure similar to the intergrowth of two different minerals with variable compositions (Figure $3(\mathrm{~g})$ and Figure $3(\mathrm{~h})$ ). Along with the increasing complexity of the textural information, there is an increase in the compositional complexity of the operating substitutions, resulting in depletion/enrichment of LREE, Th and U between zones. Although the cheralite and huttonite substitutions, and their $\mathrm{U}$ equivalents, are dominant, many of the other substitutions, especially those involving $\mathrm{Y}$, have been analysed using electron probe microanalyzer (EPMA) on several monazite grains (Supplementary Table 1 and Table 2).

Monazite-bearing dikes also comprise monazite grains with homogeneous or weakly zoned as expressed in SEM and elemental X-ray maps. The homogeneous grains, display euhedral to subhedral grain morphology, which contain abundant thorite. Most of the thorite occurs as irregular grains of a few microns and typically $20-50 \mu \mathrm{m}$ (Figures 3(i)). In transmitted light, it is yellow-green, brownish yellow, black (Figure 2(b) and Figure 2(c)). Usually, the grains are corroded, cracked and contain a scattering of holes or tiny inclusions.

Chemical zoning consists of three zones that grade from a LREE (Ce)-rich to a Th-rich composition toward the grain boundaries as identified in elemental X-ray maps (Figures 5(b)-(L), Supplementary Table 1 and Table 2). Elemental $\mathrm{X}$-ray maps (Th, Ce and $\mathrm{Y}$ ) displayed different degrees of complexity and boundary locations for specific chemical regions, best represented in the Th and LREE maps.

The high affinity of Th for the monazite structure is reflected in many samples of concentric growth zoning (Figures 5(a)-(d)), with differences among the individual growth zones typically reflecting huttonite solid-solution series in Th-rich monazite [26] [27]. In contrast to the sector-zoning monazites in some selected monazites (Figures 5(f)-(h)) are larger (up to $300 \mu \mathrm{m}$ diameter; long axis up to $500 \mu \mathrm{m}$ long) and complexly-zoned in Th and LREE with sharp or diffuse boundaries separating the sector chemically zoned grain interiors (Figures 5(i)-(L)). Specifically, elemental distribution of $\mathrm{Y}$ has not gained popularity for differentiating monazite growth zones, because monazite generally contains less than $1 \mathrm{wt} \% \mathrm{Y}_{2} \mathrm{O}_{3}$. However, some monazite grains included within garnet (Figure 5(L)) exhibit Y-enrichment towards the rim (Figure 6(d)), or have patchy core zones enriched in yttrium and thorium (Figure 5(L)). Y-rich zones/rims in monazites have been described by other workers [28] [29] [30] from migmatitic rocks, and have generally been interpreted as representing a monazite generation which grew during breakdown of garnet and/or in equilibrium with xenotime. The chemical analysis and BSE images indicate that most monazites from these samples are magmatic rather than metamorphic origin. 


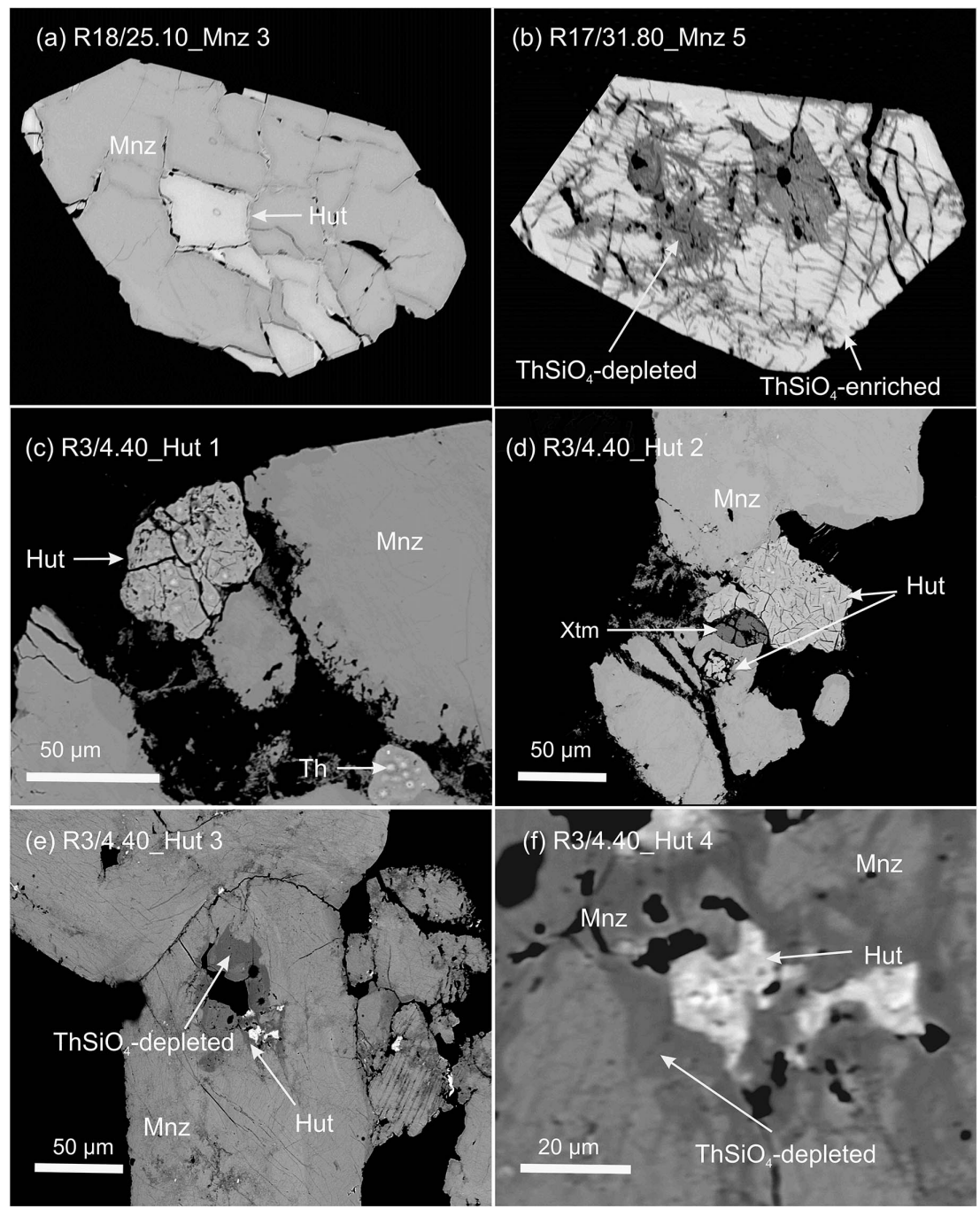

Figure 6. BSE photos showing a monazite grains that have been replaced by huttonite; (a) monazite grain replaced by huttonite (Hut) as linear intergrowth with sharp compositional boundaries; (b) the depleted or enriched in $\mathrm{ThSiO}_{4}-\mathrm{CaTh}\left(\mathrm{PO}_{4}\right)_{2}$ in the monazite grain; (c, d) irregular huttonite (Hut) domains within cracks and fractures in a monazite crystals; $(e, f)$ internal alteration occurs in a monazite crystal from sample $\mathrm{R} 3 / 4.40$, showing the $\mathrm{ThSiO}_{4}$-depleted and enriched regions.

\subsection{Monazite-Huttonite Relationships}

In magmatic and post-magmatic fluid interaction evolution, monazite may display extensive solid-solutions including the huttonite substitution. The substitution relating huttonite to monazite in our studied grains is a simple coupled substitution of $\mathrm{P}$ by $\mathrm{Si}$ at the $\mathrm{B}$ site, balanced by Th-REE substitution in the A site: $\mathrm{Th}^{4+}+\mathrm{Si}^{4+} \leftrightharpoons \mathrm{REE}^{3+}+\mathrm{P}^{5+}$, with low cheralite component, as indicated by its very low Ca content (Table 2 and Table 3 ). Th-rich monazite may occur as complex textures [31] [32] [33] [34] [35] that have been interpreted as being due to the partial metasomatism of the monazite grain during diagenesis or low-grade metamorphism [36] [37]. Common to these textures is a $\mathrm{ThSiO}_{4}$ phase including in the monazite grains that are typically characterized by a fine-grained, polycrys- 
talline mass made up of randomly oriented crystals less than $1 \mu \mathrm{m}$ in size partially enclose a subset of the monazite grains in addition to growing along fractures or filling the vugs and cracks in the monazite (Figure 6). In the samples described in this study, Th in the system will be strongly partitioned into the monazite as the monoclinic huttonite $\left(\mathrm{ThSiO}_{4}\right)$ and/or cheralite $\left[\mathrm{CaTh}\left(\mathrm{PO}_{4}\right)_{2}\right]$ component through the coupled substitutions $\mathrm{Th}^{4+}+\mathrm{Si}^{4+} \leftrightharpoons \mathrm{REE}^{3+}+\mathrm{P}^{5+}$ and $\mathrm{Th}^{4+}+\mathrm{Ca}^{2+} \leftrightharpoons 2 \mathrm{REE}^{3+}$, respectively [38] [39] [40]. On the basis of textural evidence, monazite grains can be partially or totally altered with respect to the Th and $(\mathrm{Y}+\mathrm{REE})$ distribution and content (Figure 6). Th-rich minerals (Th-rich monazite, huttonite/thorite) are more affected by alteration than Th-poor phases. This may be due to chemical disequilibrium at low-temperatures or partial metamictization before alteration [41]. During alteration, Th is gained or lost by monazite in variable amounts such that domains consist of linear intergrowth with sharp compositional boundaries (Figure 6(a)), either depleted or enriched in $\mathrm{ThSiO}_{4}-\mathrm{CaTh}\left(\mathrm{PO}_{4}\right)_{2}$ in the original monazite grains (Figure 6(b)). In all cases, the $\mathrm{ThSiO}_{4}$-depleted zones are lower in $\mathrm{Th}, \mathrm{Si}, \mathrm{Pb}$, and $\mathrm{U}$ and higher in $\mathrm{P}, \mathrm{Ca}$, REE, $\mathrm{Y}$, and $\mathrm{OH}$ suggesting that these regions have probably undergone hydrous alteration to hydro thorite (a highly hydrous thorite). Alteration occurs as irregular domains along cracks adjacent to fractures, at the contact with inclusions, and as large internal portions of the grain. A particularly good example of internal alteration occurs in a crystal from sample R3/4.40 (Figures 6(c)-(f)). An EPMA traverse, in $5 \mu \mathrm{m}$ increments across the four huttonite grains in sample $\mathrm{R} 3 / 4.40$, was made for $\mathrm{Th}$ and $\mathrm{Si}$ and other elements (oxide wt\%) using the same EPMA conditions as described above. The composition of studied huttonite is dominated by the major components $\mathrm{Th}\left(61.0-65.43 \mathrm{wt} \% \mathrm{ThO}_{2}\right)$ and $\mathrm{Si}(13.27$ $\left.17.64 \mathrm{wt} \% \mathrm{SiO}_{2}\right)$. P and $\mathrm{U}$ are always present at lesser amounts (2.68 - $6.29 \mathrm{wt} \%$ $\left.\mathrm{P}_{2} \mathrm{O}_{5} ; \leq 0.56 \mathrm{wt} \% \mathrm{UO}_{2}\right)$. The sum of $\mathrm{Y}_{2} \mathrm{O}_{3}$ and $\mathrm{REE}_{2} \mathrm{O}_{3}$ ranges from 3.97 to 12.92 wt\%. Y, Ce, Nd, Sm and Gd are invariably present in concentrations above 1 wt\%; however, La, Pr, Tb, Dy, Ho, Er, $\mathrm{Yb}$ and Lu are less than $1 \mathrm{wt} \%$ (Table 1). The $\mathrm{Ca}, \mathrm{Fe}$ and $\mathrm{Mg}$ contents in huttonite grains vary from 1.13 to $1.97 \mathrm{wt} \% \mathrm{CaO}$, 0.99 to $4.41 \mathrm{wt} \% \mathrm{Fe}_{2} \mathrm{O}_{3}$ and from 0.0 to $7.5 \mathrm{wt} \% \mathrm{MgO}$, respectively. The analytical totals are consistently $95 \%-100 \%$ with cation proportions in approximately the correct stoichiometry for $\mathrm{ThSiO}_{4}$ (Supplementary data, Table 3). Totals less than $100 \%$ for thorite are commonly reported in the literature and, as outlined in detail by Förster [42] [43], may potentially be related to one or more of: 1) the presence of absorbed molecular water or hydroxyl substituted for silica; 2) the presence of elements not included in the analytical routine; and 3) presence of uranium VI oxide.

The studied huttonite is highest in the light-rare-earth elements (LREE), with a proportion of $\mathrm{LREE}_{2} \mathrm{O}_{3}$ to $\left(\mathrm{Y}_{2} \mathrm{O}_{3}+\mathrm{HREE}_{2} \mathrm{O}_{3}\right)$ between 1.5 and 2.9. In terms of mole fractions, $\mathrm{ThSiO}_{4}$ is the dominating component (65.4 - 77.8 mol.\%). The monazite $\left(\mathrm{LREEPO}_{4}\right)$ component amounts to 3.0 - 8.4 mol.\%, whereas (Y, HREE) $\mathrm{PO}_{4}$ accounts for $1.3-5.1 \mathrm{~mol} \%$ of the huttonite composition. The cheralite 
T. Al-Ani et al.

Table 1. Representative composition of huttonite from Kovela granite sample R3/4.40. Hut ${ }^{\star}$ and Thr ${ }^{\star}$ : Type locality huttonite and thorite [42].

\begin{tabular}{|c|c|c|c|c|c|c|c|c|}
\hline Sample & Hut1_P2 & Hut1_P3 & Hut2_P4 & Hut2_P8 & Hut3_P4 & Hut3_P5 & Hut * & Thr ${ }^{\star}$ \\
\hline $\mathrm{SiO}_{2}$ (wt.\%) & 16.75 & 17.64 & 14.78 & 14.93 & 15.36 & 15.48 & 18.78 & 18.84 \\
\hline $\mathrm{CaO}$ & 1.13 & 1.55 & 1.84 & 1.56 & 1.52 & 1.67 & 0.01 & 0.13 \\
\hline $\mathrm{P}_{2} \mathrm{O}_{5}$ & 0.07 & 0.07 & 0.01 & 0.56 & 0.05 & 0.07 & 0.66 & 5.90 \\
\hline $\mathrm{PbO}$ & 64.58 & 64.54 & 62.45 & 62.20 & 62.96 & 61.70 & 79.21 & 73.46 \\
\hline $\mathrm{ThO}_{2}$ & 0.00 & 0.40 & 0.18 & 1.12 & 0.01 & 0.50 & 0.03 & 0.43 \\
\hline $\mathrm{UO}_{2}$ & 3.63 & 2.68 & 5.65 & 4.39 & 4.48 & 3.86 & 0.43 & 0.12 \\
\hline $\mathrm{Y}_{2} \mathrm{O}_{3}$ & 1.95 & 0.75 & 2.86 & 2.55 & 2.30 & 2.55 & 0.35 & 0.21 \\
\hline $\mathrm{La}_{2} \mathrm{O}_{3}$ & 0.20 & 0.13 & 0.32 & 0.36 & 0.19 & 0.22 & 0.02 & 0.00 \\
\hline $\mathrm{Ce}_{2} \mathrm{O}_{3}$ & 1.53 & 0.95 & 2.46 & 2.26 & 1.76 & 1.65 & 0.06 & 0.08 \\
\hline $\mathrm{Pr}_{2} \mathrm{O}_{3}$ & 0.26 & 0.12 & 0.49 & 0.18 & 0.39 & 0.43 & 0.02 & 0.02 \\
\hline $\mathrm{Nd}_{2} \mathrm{O}_{3}$ & 1.82 & 0.91 & 2.63 & 2.45 & 1.93 & 2.14 & 0.12 & 0.07 \\
\hline $\mathrm{Sm}_{2} \mathrm{O}_{3}$ & 0.89 & 0.32 & 1.53 & 1.15 & 1.05 & 1.14 & 0.06 & 0.04 \\
\hline $\mathrm{Gd}_{2} \mathrm{O}_{3}$ & 0.92 & 0.52 & 1.56 & 1.33 & 1.37 & 1.24 & 0.10 & 0.04 \\
\hline $\mathrm{Dy}_{2} \mathrm{O}_{3}$ & 0.30 & 0.09 & 0.54 & 0.82 & 0.65 & 0.52 & 0.06 & 0.04 \\
\hline $\mathrm{Ho}_{2} \mathrm{O}_{3}$ & 0.00 & 0.02 & 0.08 & 0.01 & 0.00 & 0.05 & 0.00 & 0.00 \\
\hline $\mathrm{Er}_{2} \mathrm{O}_{3}$ & 0.14 & 0.05 & 0.15 & 0.31 & 0.39 & 0.17 & 0.00 & 0.00 \\
\hline $\mathrm{Yb}_{2} \mathrm{O}_{3}$ & 0.19 & 0.07 & 0.18 & 0.11 & 0.22 & 0.23 & 0.00 & 0.00 \\
\hline $\mathrm{Lu}_{2} \mathrm{O}_{3}$ & 0.04 & 0.04 & 0.00 & 0.00 & 0.11 & 0.01 & 0.00 & 0.00 \\
\hline \multirow[t]{2}{*}{ Total } & 94.4 & 90.85 & 97.71 & 96.29 & 94.74 & 93.63 & 99.91 & 99.38 \\
\hline & \multicolumn{8}{|c|}{ Structural formulae based on 16 oxygen atoms } \\
\hline Si (apfu.) & 3.30 & 3.61 & 2.94 & 3.08 & 3.11 & 3.20 & 3.99 & 4.04 \\
\hline $\mathrm{Ca}$ & 0.24 & 0.34 & 0.39 & 0.34 & 0.33 & 0.37 & 0.00 & 0.03 \\
\hline $\mathrm{P}$ & 0.00 & 0.00 & 0.00 & 0.03 & 0.00 & 0.00 & 0.03 & 0.28 \\
\hline $\mathrm{Pb}$ & 2.89 & 3.01 & 2.83 & 2.92 & 2.90 & 2.90 & 3.83 & 3.59 \\
\hline $\mathrm{Th}$ & 0.00 & 0.02 & 0.01 & 0.06 & 0.00 & 0.03 & 0.00 & 0.02 \\
\hline $\mathrm{U}$ & 0.60 & 0.46 & 0.95 & 0.77 & 0.77 & 0.67 & 0.08 & 0.02 \\
\hline $\mathrm{Y}$ & 0.20 & 0.08 & 0.30 & 0.28 & 0.25 & 0.28 & 0.04 & 0.02 \\
\hline $\mathrm{La}$ & 0.01 & 0.01 & 0.02 & 0.03 & 0.01 & 0.02 & 0.00 & 0.00 \\
\hline $\mathrm{Ce}$ & 0.11 & 0.07 & 0.18 & 0.17 & 0.13 & 0.12 & 0.00 & 0.01 \\
\hline $\operatorname{Pr}$ & 0.02 & 0.01 & 0.04 & 0.01 & 0.03 & 0.03 & 0.00 & 0.00 \\
\hline $\mathrm{Nd}$ & 0.13 & 0.07 & 0.19 & 0.18 & 0.14 & 0.16 & 0.01 & 0.01 \\
\hline $\mathrm{Sm}$ & 0.06 & 0.02 & 0.10 & 0.08 & 0.07 & 0.08 & 0.00 & 0.00 \\
\hline $\mathrm{Gd}$ & 0.06 & 0.04 & 0.10 & 0.09 & 0.09 & 0.08 & 0.01 & 0.00 \\
\hline Dy & 0.02 & 0.01 & 0.03 & 0.05 & 0.04 & 0.03 & 0.00 & 0.00 \\
\hline Ho & 0.00 & 0.00 & 0.01 & 0.00 & 0.00 & 0.00 & 0.00 & 0.00 \\
\hline Er & 0.01 & 0.00 & 0.01 & 0.02 & 0.02 & 0.01 & 0.00 & 0.00 \\
\hline $\mathrm{Yb}$ & 0.01 & 0.00 & 0.01 & 0.01 & 0.01 & 0.01 & 0.00 & 0.00 \\
\hline $\mathrm{Lu}$ & 0.00 & 0.00 & 0.00 & 0.00 & 0.01 & 0.00 & 0.00 & 0.00 \\
\hline Total & 7.66 & 7.75 & 8.11 & 8.12 & 7.91 & 7.99 & 7.99 & 8.02 \\
\hline
\end{tabular}


CaTh $\left(\mathrm{PO}_{4}\right)_{2}$, component is present in the range between 13.5 and $22.4 \mathrm{~mol} . \%$ (Figure 8(a)). Incorporation of the REE and $\mathrm{Y}$ into the huttonite structure takes place mainly by the coupled substitution $\mathrm{REE}^{3+}+\mathrm{P}^{5+} \leftrightharpoons \mathrm{Th}^{4+}+\mathrm{Si}^{4+}$. The electron-microprobe data for the huttonite grains presented here show good correspondence with the experimental data on huttonite-thorite phase of Gillespie's Beach, New Zealand [42]. The individual lanthanide elements of the studied huttonite were established in decreasing order of abundance as: $\mathrm{Y}>\mathrm{Gd}, \mathrm{Nd}>$ Ce, Sm, Dy $>$ La, Pr. This established composition is reasonably similar to the average electron-microprobe analyses of huttonite from its type locality, Gillespie's Beach, southern Westland, New Zealand [42]. Huttonite from the Kovela granitic complex contains lower $\mathrm{ThO}_{2}(61.0-65.43 \mathrm{wt} \%), \mathrm{SiO}_{2}(13.27-17.64$ wt\%) and $\mathrm{UO}_{2}(0.0-0.6 \mathrm{wt} \%)$, and higher $\mathrm{Y}_{2} \mathrm{O}_{3}(0.8-2.9 \mathrm{wt} \%)$ and $\mathrm{REE}_{2} \mathrm{O}_{3}(3.2-$ $10.0 \mathrm{wt} \%)$ compared to average composition of huttonite (Table 1).

\subsection{REE Distribution in Monazites}

The different textural types of the studied monazite-(Ce) occupy a small compositional range and show small variations of oxides (full analytical data in Supplementary Table 1 and Table 2). The monazite from Kovela granitic complex mostly has elevated $\mathrm{Th}+\mathrm{U}$ contents, with a predominance of Th over $\mathrm{U}$. Representative microprobe analyses of monazite from the core, mantle and rim regions are presented in Table 2 and Table 3 . The zonation displayed by the BSE images (Figure 3) reflects the overall chemical compositional variation within single monazite crystal. The concentrations (in wt\%) of Th and $U$ are at a level common for granitic rocks and vary only in a narrow interval varies in the range of 1.05 to $1.43 \mathrm{apfu}$ (12.97 to $18.31 \mathrm{wt} \% \mathrm{ThO}_{2}$ ). The $\mathrm{U}$ content is low and ranges between 0.02 to $0.06 \mathrm{apfu}\left(0.21\right.$ to $0.74 \mathrm{wt} \% \mathrm{UO}_{2}$ ). The $\mathrm{Si}$ and Ca contents (2.52 to $3.60 \mathrm{wt} \% \mathrm{SiO}_{2}, 0.90$ to $1.27 \mathrm{apfu} \mathrm{Si}$ and 0.77 to $0.91 \mathrm{wt} \% \mathrm{CaO}, 0.28$ to 0.34 ap$\mathrm{fu} \mathrm{Ca}$ ) indicate that $\mathrm{Th}$ is primarily incorporated into the monazite structure due to the substitution of both huttonite/thorite $\left[(\mathrm{Th}, \mathrm{U}) \mathrm{Si}(\mathrm{REE})_{-1} \mathrm{P}_{-1}\right]$ and cheralite [Ca(Th,U) $\mathrm{REE}_{-2}$ ] [44] [45]. Thorium and $\mathrm{U}$ are usually substituted as huttonite/thorite according to the following reactions:

$$
\begin{gathered}
(\mathrm{Th}, \mathrm{U})^{4+}+\mathrm{Si}^{4+} \leftrightharpoons \mathrm{REE}^{3+}+\mathrm{P}^{5+} \\
(\mathrm{Th}, \mathrm{U})^{4+}+\mathrm{Ca}^{2+} \leftrightharpoons 2 \mathrm{REE}^{3+}
\end{gathered}
$$

The compositional range of the monazites is shown in the diagram $(\mathrm{P}+\mathrm{Y}+$ $\mathrm{REE}$ ) versus $(\mathrm{Si}+\mathrm{Th}+\mathrm{U}$ ) diagram (Figure 7(a) and Figure 7(b)). Monazite grains of concentric zoning plot on a narrow interval field at the huttonite substitution curve and show systematic core-rim compositional variation. Cores have relatively low Th and high REE contents but rims have distinctly higher Th and $\mathrm{Si}$ (Figure 7(a)). Monazite of sector or "intergrowth-like" zoning have been plotting along the vector representing the huttonite substitution, (Th, U)Si (REE)-1P-1. However, a few of the analyses of monazite grains (e.g. R17/23.30_Mnz 3 \& 4) plot in the center of monazite vector (Figure 7(b)). 
Table 2. Representative electron microprobe analyses of monazite from Kovela granitic complex, sample R3/2.35_Mnz 4.

\begin{tabular}{|c|c|c|c|c|c|c|c|c|c|c|}
\hline Sample & Mnz4_p1 & Mnz4_p2 & Mnz4_p3 & Mnz4_p4 & Mnz4_p5 & Mnz4_p6 & Mnz4_p7 & Mnz4_p8 & Mnz4_p9 & Mnz4_p10 \\
\hline Comment & \multicolumn{2}{|c|}{$\operatorname{Rim}$} & \multicolumn{2}{|c|}{ Intermediate } & \multicolumn{4}{|c|}{ Core } & \multicolumn{2}{|c|}{ Rim } \\
\hline $\mathrm{SiO}_{2}(\mathrm{wt} \%)$ & 3.73 & 3.26 & 3.34 & 1.71 & 1.78 & 1.42 & 1.38 & 2.06 & 3.19 & 3.29 \\
\hline $\mathrm{FeO}$ & 0.03 & 0.03 & 0.00 & 0.02 & 0.08 & 0.04 & 0.03 & 0.07 & 0.01 & 0.03 \\
\hline $\mathrm{MgO}$ & 0.90 & 0.88 & 0.83 & 0.78 & 0.56 & 0.72 & 0.71 & 0.74 & 0.81 & 0.83 \\
\hline $\mathrm{CaO}$ & 22.99 & 23.74 & 23.69 & 25.98 & 25.63 & 26.66 & 26.79 & 26.47 & 23.59 & 23.68 \\
\hline $\mathrm{P}_{2} \mathrm{O}_{5}$ & 1.12 & 1.10 & 1.02 & 0.52 & 0.25 & 0.40 & 0.40 & 0.41 & 0.98 & 1.06 \\
\hline $\mathrm{PbO}$ & 19.40 & 17.09 & 17.56 & 9.54 & 9.24 & 7.95 & 7.91 & 7.55 & 16.61 & 16.81 \\
\hline $\mathrm{ThO}_{2}$ & 0.26 & 0.23 & 0.30 & 0.21 & 0.10 & 0.21 & 0.19 & 0.12 & 0.21 & 0.22 \\
\hline $\mathrm{UO}_{2}$ & 0.90 & 0.84 & 0.87 & 1.05 & 0.60 & 1.06 & 1.11 & 1.05 & 0.81 & 0.86 \\
\hline $\mathrm{Y}_{2} \mathrm{O}_{3}$ & 9.51 & 10.20 & 10.08 & 11.64 & 11.92 & 11.71 & 11.64 & 11.77 & 10.27 & 10.21 \\
\hline $\mathrm{La}_{2} \mathrm{O}_{3}$ & 25.83 & 26.83 & 26.52 & 30.44 & 31.46 & 30.82 & 31.22 & 30.87 & 27.21 & 27.06 \\
\hline $\mathrm{Ce}_{2} \mathrm{O}_{3}$ & 2.88 & 3.00 & 2.95 & 3.24 & 3.19 & 3.33 & 3.34 & 3.23 & 2.90 & 3.04 \\
\hline $\mathrm{Pr}_{2} \mathrm{O}_{3}$ & 9.36 & 9.44 & 9.45 & 10.30 & 10.36 & 10.64 & 10.52 & 10.30 & 9.56 & 9.53 \\
\hline $\mathrm{Nd}_{2} \mathrm{O}_{3}$ & 1.55 & 1.52 & 1.51 & 1.53 & 1.60 & 1.61 & 1.66 & 1.67 & 1.38 & 1.48 \\
\hline $\mathrm{Sm}_{2} \mathrm{O}_{3}$ & 0.96 & 0.99 & 0.99 & 1.20 & 0.94 & 1.12 & 1.08 & 1.00 & 0.93 & 0.93 \\
\hline $\mathrm{Gd}_{2} \mathrm{O}_{3}$ & 0.20 & 0.25 & 0.23 & 0.29 & 0.20 & 0.24 & 0.28 & 0.34 & 0.33 & 0.21 \\
\hline $\mathrm{Dy}_{2} \mathrm{O}_{3}$ & 0.00 & 0.00 & 0.03 & 0.00 & 0.02 & 0.00 & 0.00 & 0.04 & 0.00 & 0.00 \\
\hline $\mathrm{Ho}_{2} \mathrm{O}_{3}$ & 0.00 & 0.11 & 0.15 & 0.07 & 0.02 & 0.07 & 0.00 & 0.05 & 0.05 & 0.09 \\
\hline $\mathrm{Er}_{2} \mathrm{O}_{3}$ & 0.00 & 0.00 & 0.00 & 0.01 & 0.02 & 0.00 & 0.03 & 0.01 & 0.01 & 0.00 \\
\hline $\mathrm{Yb}_{2} \mathrm{O}_{3}$ & 0.00 & 0.02 & 0.00 & 0.02 & 0.02 & 0.02 & 0.01 & 0.01 & 0.00 & 0.03 \\
\hline $\mathrm{F}$ & 0.52 & 0.54 & 0.52 & 0.59 & 0.63 & 0.64 & 0.65 & 0.56 & 0.57 & 0.52 \\
\hline $\mathrm{F}=\mathrm{O}$ & -0.22 & -0.23 & -0.22 & -0.25 & -0.26 & -0.27 & -0.27 & -0.23 & -0.24 & -0.22 \\
\hline $\mathrm{Cl}$ & 0.02 & 0.02 & 0.03 & 0.04 & 0.03 & 0.03 & 0.03 & 0.03 & 0.03 & 0.03 \\
\hline $\mathrm{Cl}=\mathrm{O}$ & 0.00 & 0.00 & -0.01 & -0.01 & -0.01 & -0.01 & -0.01 & -0.01 & -0.01 & -0.01 \\
\hline \multirow[t]{2}{*}{ Total } & 99.93 & 99.86 & 99.84 & 98.94 & 98.38 & 98.41 & 98.70 & 98.11 & 99.20 & 99.69 \\
\hline & \multicolumn{10}{|c|}{ Structural formulae based on 16 oxygen atoms } \\
\hline $\mathrm{Si}$ (apfu.) & 1.265 & 1.129 & 1.154 & 0.641 & 0.675 & 0.542 & 0.526 & 0.769 & 1.117 & 1.145 \\
\hline $\mathrm{Fe}$ & 0.009 & 0.008 & 0.000 & 0.007 & 0.024 & 0.011 & 0.010 & 0.023 & 0.002 & 0.008 \\
\hline $\mathrm{Ca}$ & 0.327 & 0.328 & 0.307 & 0.312 & 0.228 & 0.295 & 0.288 & 0.296 & 0.306 & 0.310 \\
\hline $\mathrm{P}$ & 3.305 & 3.484 & 3.467 & 4.125 & 4.101 & 4.297 & 4.314 & 4.190 & 3.498 & 3.484 \\
\hline $\mathrm{Pb}$ & 0.103 & 0.103 & 0.095 & 0.053 & 0.025 & 0.041 & 0.041 & 0.041 & 0.093 & 0.099 \\
\hline Th & 1.499 & 1.348 & 1.382 & 0.815 & 0.795 & 0.689 & 0.684 & 0.643 & 1.324 & 1.330 \\
\hline $\mathrm{U}$ & 0.020 & 0.018 & 0.023 & 0.018 & 0.008 & 0.017 & 0.016 & 0.010 & 0.017 & 0.017 \\
\hline Y & 0.072 & 0.068 & 0.071 & 0.093 & 0.053 & 0.094 & 0.099 & 0.093 & 0.067 & 0.070 \\
\hline $\mathrm{La}$ & 0.595 & 0.652 & 0.642 & 0.805 & 0.831 & 0.823 & 0.817 & 0.812 & 0.663 & 0.655 \\
\hline $\mathrm{Ce}$ & 1.605 & 1.702 & 1.678 & 2.090 & 2.177 & 2.148 & 2.174 & 2.113 & 1.745 & 1.722 \\
\hline $\operatorname{Pr}$ & 0.178 & 0.189 & 0.186 & 0.222 & 0.220 & 0.231 & 0.232 & 0.220 & 0.185 & 0.193 \\
\hline $\mathrm{Nd}$ & 0.567 & 0.584 & 0.583 & 0.690 & 0.699 & 0.724 & 0.715 & 0.688 & 0.598 & 0.591 \\
\hline $\mathrm{Sm}$ & 0.091 & 0.091 & 0.090 & 0.099 & 0.104 & 0.106 & 0.109 & 0.108 & 0.083 & 0.089 \\
\hline $\mathrm{Gd}$ & 0.054 & 0.057 & 0.057 & 0.074 & 0.059 & 0.071 & 0.068 & 0.062 & 0.054 & 0.054 \\
\hline Dy & 0.011 & 0.014 & 0.013 & 0.018 & 0.012 & 0.014 & 0.017 & 0.021 & 0.019 & 0.011 \\
\hline
\end{tabular}


Continued

\begin{tabular}{cccccccccccc}
\hline Ho & 0.000 & 0.000 & 0.002 & 0.000 & 0.001 & 0.000 & 0.000 & 0.002 & 0.000 & 0.000 \\
$\mathrm{Er}$ & 0.000 & 0.006 & 0.008 & 0.004 & 0.001 & 0.004 & 0.000 & 0.003 & 0.003 & 0.005 \\
$\mathrm{Yb}$ & 0.000 & 0.000 & 0.000 & 0.001 & 0.001 & 0.000 & 0.002 & 0.001 & 0.000 & 0.000 \\
$\mathrm{Lu}$ & 0.000 & 0.001 & 0.000 & 0.001 & 0.001 & 0.001 & 0.001 & 0.001 & 0.000 & 0.002 \\
$\mathrm{~F}$ & 0.553 & 0.591 & 0.573 & 0.700 & 0.748 & 0.769 & 0.779 & 0.659 & 0.627 & 0.573 \\
Total & 10.254 & 10.375 & 10.330 & 10.766 & 10.765 & 10.879 & 10.890 & 10.752 & 10.399 & 10.357 \\
\hline
\end{tabular}

Table 3. Representative electron microprobe analyses of monazite from Kovela granitic complex,sample R8/17.80_Mnz 3.

\begin{tabular}{|c|c|c|c|c|c|c|c|c|c|c|}
\hline Sample & Mnz3_p1 & Mnz3_p11 & Mnz3_p15 & Mnz3_p20 & Mnz3_p24 & Mnz3_p30 & Mnz3_p33 & Mnz3_p40 & Mnz3_p48 & Mnz3_p55 \\
\hline Comment & \multicolumn{2}{|c|}{ Rim } & \multicolumn{2}{|c|}{ Intermediate } & \multicolumn{2}{|c|}{ Core } & \multicolumn{2}{|c|}{ Intermediate } & \multicolumn{2}{|c|}{ Core } \\
\hline $\mathrm{SiO}_{2}(\mathrm{wt} \%)$ & 3.58 & 3.80 & 3.36 & 3.03 & 2.79 & 2.84 & 2.83 & 3.29 & 4.16 & 4.01 \\
\hline $\mathrm{FeO}$ & 0.02 & 0.01 & 0.02 & 0.04 & 0.15 & 0.07 & 0.01 & 0.00 & 0.00 & 0.00 \\
\hline $\mathrm{MgO}$ & 0.78 & 0.82 & 0.80 & 0.84 & 0.94 & 0.93 & 0.88 & 0.91 & 0.74 & 0.75 \\
\hline $\mathrm{CaO}$ & 23.10 & 22.66 & 23.29 & 23.74 & 24.27 & 24.20 & 24.20 & 23.69 & 22.38 & 22.46 \\
\hline $\mathrm{P}_{2} \mathrm{O}_{5}$ & 1.15 & 1.19 & 1.01 & 1.07 & 0.96 & 0.85 & 0.95 & 1.02 & 1.30 & 1.17 \\
\hline $\mathrm{PbO}$ & 18.45 & 19.35 & 17.37 & 16.06 & 15.38 & 15.68 & 15.59 & 17.41 & 20.41 & 20.10 \\
\hline $\mathrm{ThO}_{2}$ & 0.32 & 0.24 & 0.25 & 0.19 & 0.21 & 0.14 & 0.25 & 0.22 & 0.34 & 0.31 \\
\hline $\mathrm{UO}_{2}$ & 0.84 & 0.91 & 0.81 & 0.91 & 0.78 & 0.75 & 0.81 & 0.86 & 0.84 & 0.85 \\
\hline $\mathrm{Y}_{2} \mathrm{O}_{3}$ & 9.99 & 9.48 & 10.13 & 10.02 & 10.45 & 10.41 & 10.33 & 9.85 & 9.45 & 9.32 \\
\hline $\mathrm{La}_{2} \mathrm{O}_{3}$ & 26.19 & 25.73 & 26.65 & 27.11 & 27.73 & 27.39 & 27.55 & 26.40 & 25.40 & 25.50 \\
\hline $\mathrm{Ce}_{2} \mathrm{O}_{3}$ & 2.85 & 2.84 & 2.90 & 3.19 & 2.94 & 2.93 & 3.07 & 2.90 & 2.82 & 2.82 \\
\hline $\mathrm{Pr}_{2} \mathrm{O}_{3}$ & 9.30 & 9.26 & 9.42 & 9.77 & 9.47 & 9.49 & 9.70 & 9.71 & 9.35 & 9.10 \\
\hline $\mathrm{Nd}_{2} \mathrm{O}_{3}$ & 1.47 & 1.43 & 1.39 & 1.53 & 1.50 & 1.44 & 1.57 & 1.41 & 1.45 & 1.43 \\
\hline $\mathrm{Sm}_{2} \mathrm{O}_{3}$ & 0.92 & 0.95 & 0.95 & 1.11 & 0.90 & 0.99 & 0.95 & 0.99 & 1.03 & 1.01 \\
\hline $\mathrm{Gd}_{2} \mathrm{O}_{3}$ & 0.21 & 0.19 & 0.23 & 0.19 & 0.25 & 0.20 & 0.23 & 0.24 & 0.21 & 0.23 \\
\hline $\mathrm{Dy}_{2} \mathrm{O}_{3}$ & 0.00 & 0.00 & 0.00 & 0.00 & 0.00 & 0.00 & 0.00 & 0.03 & 0.00 & 0.00 \\
\hline $\mathrm{Ho}_{2} \mathrm{O}_{3}$ & 0.04 & 0.10 & 0.07 & 0.09 & 0.07 & 0.05 & 0.00 & 0.00 & 0.09 & 0.13 \\
\hline $\mathrm{Er}_{2} \mathrm{O}_{3}$ & 0.03 & 0.00 & 0.00 & 0.02 & 0.04 & 0.01 & 0.00 & 0.00 & 0.00 & 0.00 \\
\hline $\mathrm{Yb}_{2} \mathrm{O}_{3}$ & 0.03 & 0.00 & 0.00 & 0.04 & 0.00 & 0.00 & 0.00 & 0.00 & 0.00 & 0.05 \\
\hline $\mathrm{F}$ & 0.55 & 0.50 & 0.54 & 0.55 & 0.51 & 0.53 & 0.55 & 0.54 & 0.51 & 0.59 \\
\hline $\mathrm{F}=\mathrm{O}$ & -0.23 & -0.21 & -0.23 & -0.23 & -0.22 & -0.22 & -0.23 & -0.23 & -0.21 & -0.25 \\
\hline $\mathrm{Cl}$ & 0.02 & 0.03 & 0.02 & 0.04 & 0.02 & 0.03 & 0.03 & 0.03 & 0.01 & 0.01 \\
\hline $\mathrm{Cl}=\mathrm{O}$ & -0.01 & -0.01 & -0.01 & -0.01 & -0.01 & -0.01 & -0.01 & -0.01 & 0.00 & 0.00 \\
\hline \multirow[t]{2}{*}{ Total } & 99.61 & 99.26 & 98.98 & 99.30 & 99.13 & 98.70 & 99.27 & 99.26 & 100.27 & 99.59 \\
\hline & \multicolumn{10}{|c|}{ Structural formulae based on 16 oxygen atoms } \\
\hline Si (apfu.) & 1.230 & 1.297 & 1.170 & 1.069 & 0.989 & 1.009 & 1.003 & 1.142 & 1.393 & 1.354 \\
\hline $\mathrm{Fe}$ & 0.005 & 0.001 & 0.005 & 0.013 & 0.044 & 0.019 & 0.002 & 0.001 & 0.000 & 0.000 \\
\hline $\mathrm{Ca}$ & 0.287 & 0.300 & 0.300 & 0.317 & 0.356 & 0.352 & 0.334 & 0.337 & 0.266 & 0.273 \\
\hline $\mathrm{P}$ & 3.357 & 3.277 & 3.437 & 3.541 & 3.646 & 3.639 & 3.630 & 3.481 & 3.173 & 3.207 \\
\hline $\mathrm{Pb}$ & 0.106 & 0.109 & 0.095 & 0.101 & 0.092 & 0.082 & 0.090 & 0.096 & 0.117 & 0.107 \\
\hline Th & 1.441 & 1.504 & 1.378 & 1.288 & 1.242 & 1.267 & 1.257 & 1.375 & 1.555 & 1.543 \\
\hline $\mathrm{U}$ & 0.024 & 0.018 & 0.019 & 0.015 & 0.016 & 0.011 & 0.020 & 0.017 & 0.025 & 0.023 \\
\hline
\end{tabular}




\section{Continued}

\begin{tabular}{|c|c|c|c|c|c|c|c|c|c|c|}
\hline $\mathrm{Y}$ & 0.068 & 0.073 & 0.066 & 0.075 & 0.065 & 0.062 & 0.067 & 0.070 & 0.066 & 0.068 \\
\hline $\mathrm{La}$ & 0.632 & 0.597 & 0.651 & 0.651 & 0.684 & 0.682 & 0.675 & 0.631 & 0.583 & 0.580 \\
\hline $\mathrm{Ce}$ & 1.646 & 1.609 & 1.700 & 1.749 & 1.801 & 1.781 & 1.787 & 1.678 & 1.557 & 1.574 \\
\hline $\operatorname{Pr}$ & 0.178 & 0.176 & 0.184 & 0.205 & 0.190 & 0.190 & 0.198 & 0.183 & 0.172 & 0.173 \\
\hline $\mathrm{Nd}$ & 0.570 & 0.565 & 0.586 & 0.615 & 0.600 & 0.602 & 0.614 & 0.602 & 0.559 & 0.548 \\
\hline $\mathrm{Sm}$ & 0.087 & 0.084 & 0.083 & 0.093 & 0.092 & 0.088 & 0.096 & 0.084 & 0.084 & 0.083 \\
\hline $\mathrm{Gd}$ & 0.052 & 0.054 & 0.055 & 0.065 & 0.053 & 0.058 & 0.056 & 0.057 & 0.057 & 0.057 \\
\hline Dy & 0.012 & 0.010 & 0.013 & 0.011 & 0.014 & 0.011 & 0.013 & 0.013 & 0.012 & 0.013 \\
\hline Ho & 0.000 & 0.000 & 0.000 & 0.000 & 0.000 & 0.000 & 0.000 & 0.002 & 0.000 & 0.000 \\
\hline Er & 0.002 & 0.006 & 0.004 & 0.005 & 0.004 & 0.003 & 0.000 & 0.000 & 0.005 & 0.007 \\
\hline $\mathrm{Yb}$ & 0.002 & 0.000 & 0.000 & 0.001 & 0.002 & 0.001 & 0.000 & 0.000 & 0.000 & 0.000 \\
\hline $\mathrm{Lu}$ & 0.001 & 0.000 & 0.000 & 0.002 & 0.000 & 0.000 & 0.000 & 0.000 & 0.000 & 0.002 \\
\hline $\mathrm{F}$ & 0.594 & 0.544 & 0.591 & 0.615 & 0.575 & 0.592 & 0.618 & 0.596 & 0.540 & 0.633 \\
\hline Total & 10.297 & 10.226 & 10.339 & 10.430 & 10.465 & 10.450 & 10.461 & 10.364 & 10.163 & 10.242 \\
\hline
\end{tabular}
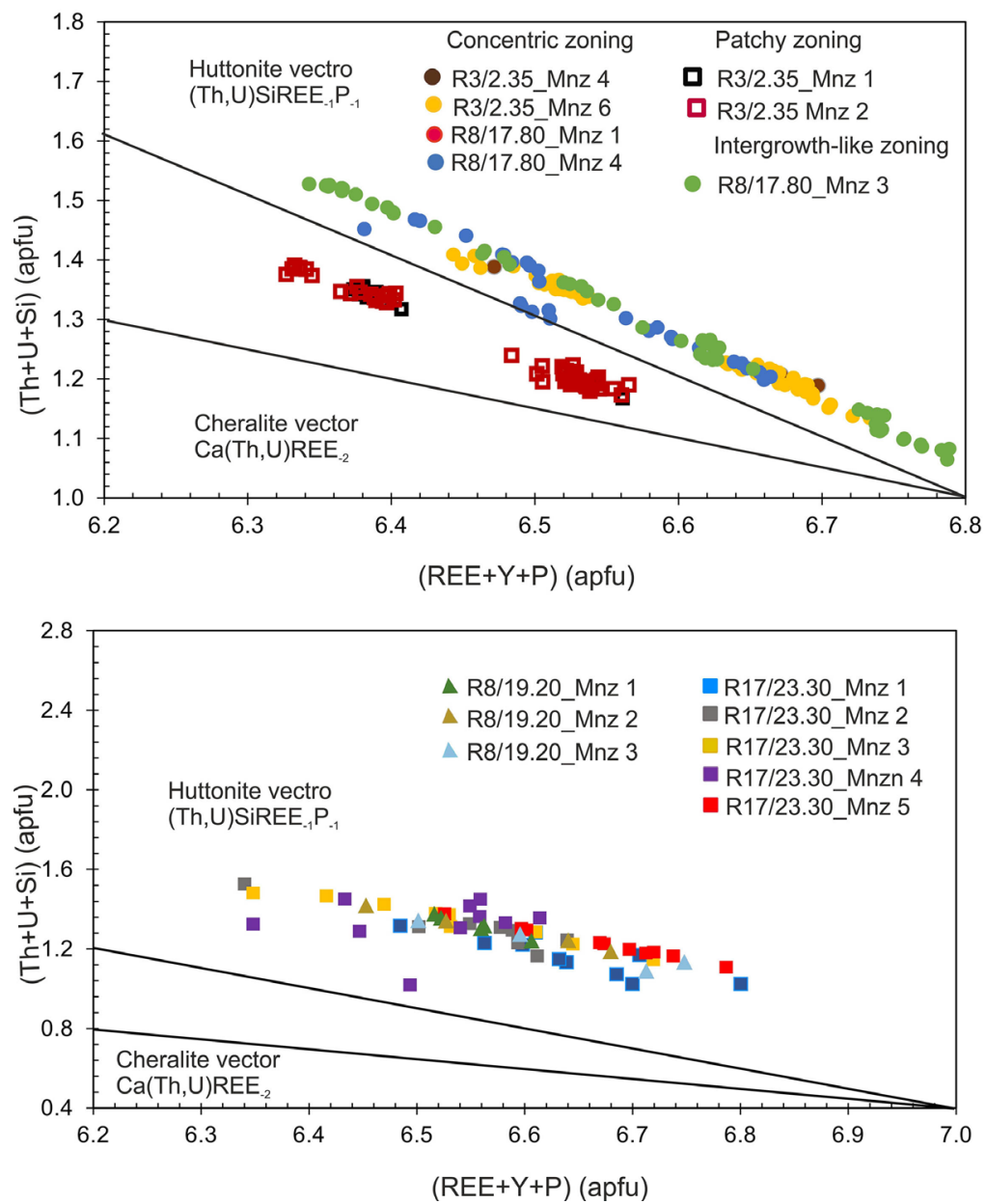

Figure 7. $(\mathrm{a}, \mathrm{b})$ Plots of formula proportions $(\mathrm{Th}+\mathrm{U}+\mathrm{Si})$ vs. $(\mathrm{REE}+\mathrm{Y}+\mathrm{P})$, calculated on the basis of 16 oxygen atoms, of monazite-(Ce) for all types of zoning patterns of monazites from the studied monazite-bearing dikes in Kovela complex. Full lines represent the exchange vectors for the huttonite and cheralite substitutions. 
The nomenclature of the monazite-group minerals can be connected with the ternary system $2 \mathrm{REEPO}_{4}$-CaTh $\left(\mathrm{PO}_{4}\right)_{2}-2 \mathrm{ThSiO}_{4}$ proposed by Linthout [46] as is given in Figure 8(a) and Figure 8(b)). This plot also shows the compositions of Th-rich monazites are more common, and these give way to monazite, huttonite-rich monazite and huttonite (Figure 9(a) and Figure 9(b)). The mole percentage of huttonite (Hut) in the studied monazite grains ranges from 16 to 27 mol.\%. In contrast, the cheralite substitution appears to be lacking in monazite-group minerals in studied granites (10 to 23 mol.\%) (Supplementary data Table 1 and Table 2).

(a)

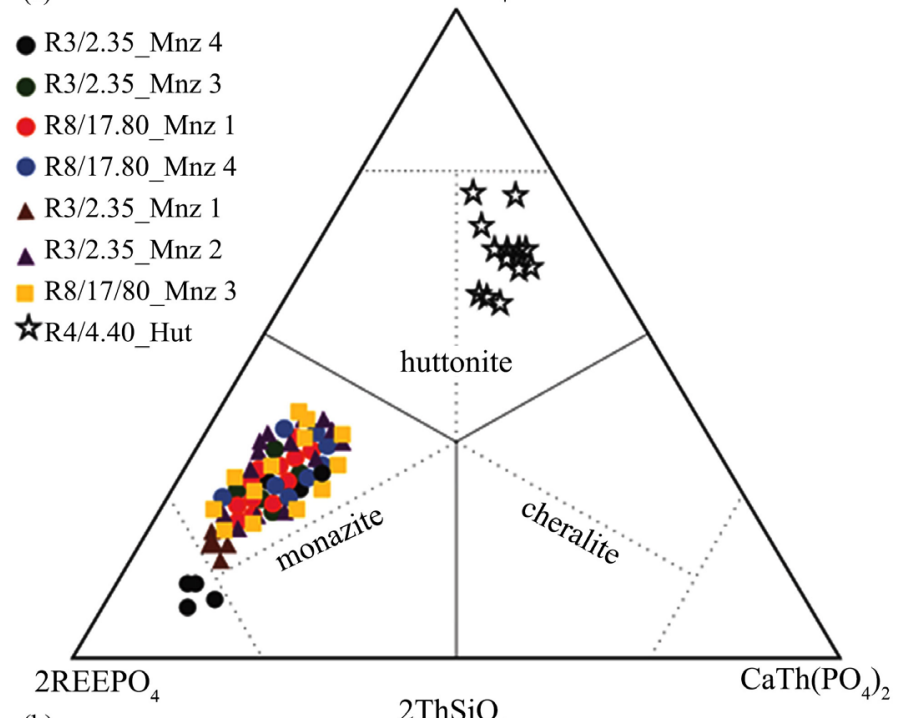

(b)

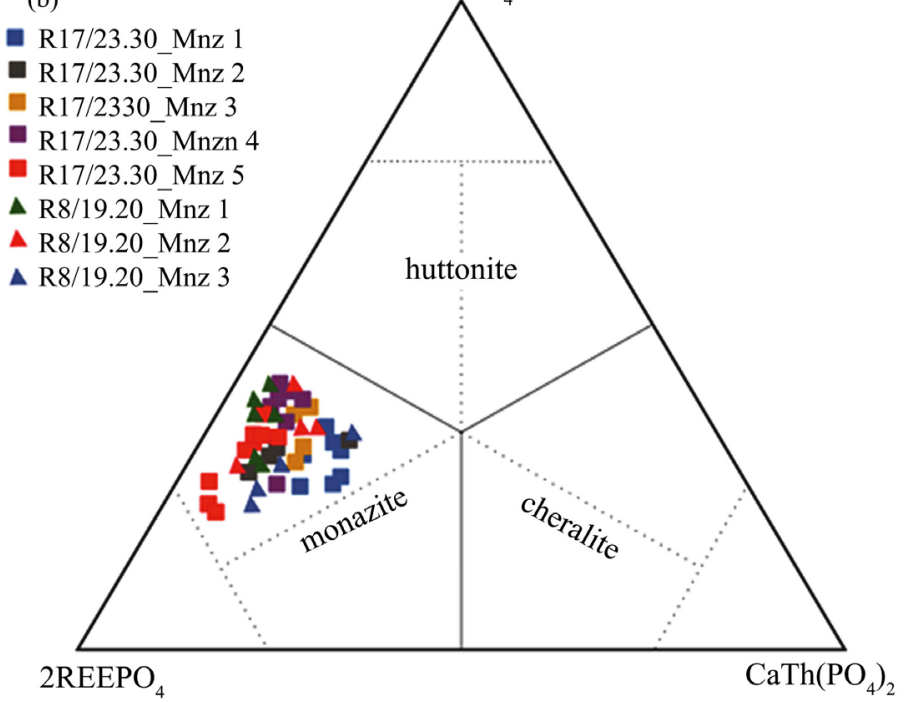

Figure 8. (a, b) Position of monazite-group minerals from the studied samples in the tripartite nomenclature diagram for the system monazite-cheralite-huttonite [46]. In computing the end-member proportions, Th is combined with $\mathrm{Si}$ in $\mathrm{ThSiO}_{4}$, the remaining $\mathrm{Th}, \mathrm{U}$, and $\mathrm{Pb}$ are combined with CaTh $\left(\mathrm{PO}_{4}\right)_{2}$, and $\mathrm{Y}$ is included in the $\mathrm{REEPO}_{4}$ component. 

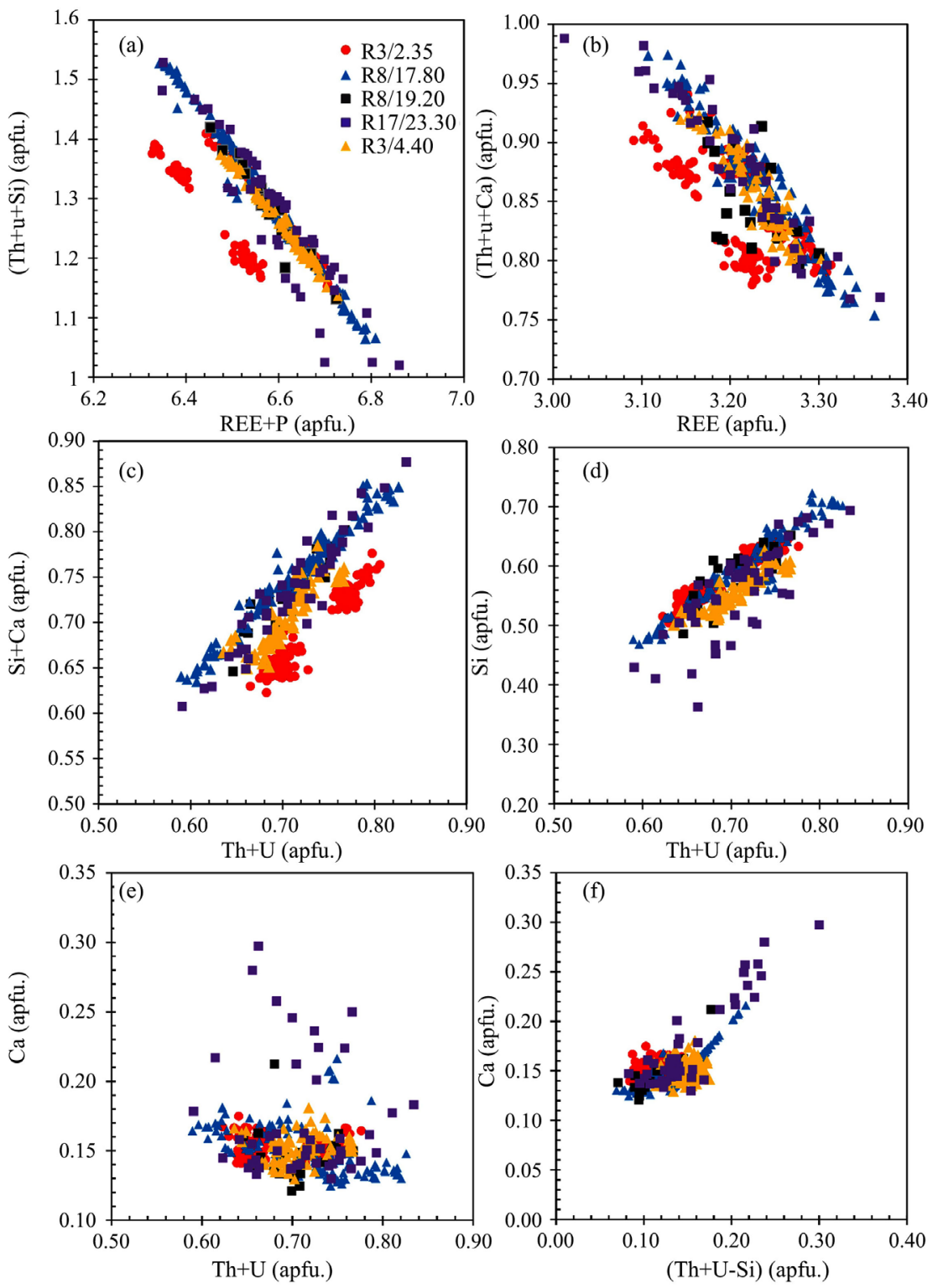

Figure 9. Compositional variation in monazite grains (analysed by EPMA, presented in cations per formula unit). ( $\mathrm{a}, \mathrm{b}$ ) Compositional trends of REE $+\mathrm{P}$ vs. Th $+\mathrm{Si}$ (huttonite substitution) and 2REE vs. (Th, U) + Ca (cheralite substitution), (c) Plot of Th + U vs. Si + Ca shows that both huttonite and cheralite contribute to the element substitutions, (d) Strong correlation of $\mathrm{Si}$ vs. Th $+\mathrm{U}$ suggests the huttonite exchange dominates in studied monazite, (e, f) Strong correlation of Ca vs. Th + U after subtracting Si (huttonite component).

The alteration of pre-existing monazite involves alteration by element depletion and enrichment controlled by the two coupled substitution mechanisms: The most common isomorphic substitution of this type is the huttonite according to reaction (1), that leads towards a huttonite end-member (Th, $\mathrm{U}$ ) $\mathrm{SiO}_{4}$, where the phosphate framework is not preserved [47] [48]. The subordinate cheralite exchange according to reaction (2), which results in a cheralite end-member composition $\mathrm{Ca}(\mathrm{Th}, \mathrm{U})\left(\mathrm{PO}_{4}\right)_{2}$ where the phosphate framework of 
the monazite is maintained [46].

Both of these substitutions can be tested through the strong negative correlation between $\mathrm{Th}+\mathrm{U}+\mathrm{Si}$ cations (normalized to 16 oxygen) and $\mathrm{REE}+\mathrm{P}$ cations (normalized to 16 oxygen) suggests that coupled substitutions (1) and (2) that have been occurred as with Si replacing $\mathrm{P}$ in the tetrahedral site and Th or $\mathrm{U}$ replacing REE in the 8-fold site (sub. 1) (Figure 9(a)). The second type of substitution in monazite involves cheralite substitution, reflecting the substitution reaction (sub. 2) (Figure 9(b)). Figure 9(c) shows a significant correlation between $\mathrm{Th}+\mathrm{U}$ vs. $\mathrm{Si}+\mathrm{Ca}$, indicating that nearly all of the $\mathrm{Th}+\mathrm{U}$ can be accommodated by the two substitution mechanisms (sub. 1,2), but with the predominance of huttonite (Figure 9(d)). The plot of $\mathrm{Ca}$ against $\mathrm{Th}+\mathrm{U}$ (Figure 9(e)) reveals no obvious correlation, but after the huttonite component has been subtracted from $\mathrm{Th}+\mathrm{U}$, and the strong correlation with $\mathrm{Ca}$ is evident (Figure 9(f)). The dominance of the huttonite exchange in the monazite grains of Kovela granitic complex is consistent with the previous indications that the huttonite exchange $\left[(\mathrm{Th}, \mathrm{U})^{4+} \leftrightharpoons \mathrm{Si}^{4+}\right]$ is more common in granitic monazite and appears to represent magmatic and postmagmatic processes. The postmagmatic stage is characterized by strong dissolution leading to the formation of fractured and altered monazite domains. Chemistry of these domains reflects enrichment in $\mathrm{P}$, Th and in some cases in $\mathrm{U}$, which cannot be explained by late magma differentiation and therefore is attributed to the fluid interaction [49] [50]. The chemical composition suggests that the fluids released these elements from the outer parts of the monazite grains and deposited them in a form of secondary minerals such as huttonite/thorite.

\section{Geochemistry}

The major elements and trace element contents of all of the analysed monazite-bearing dikes and porphyritic granite samples are presented in Supplementary data Table 4. Monazite-bearing dikes and associated porphyritic granites display typical granitic composition with a $\mathrm{SiO}_{2}$ content of $62.8 \mathrm{wt} \%, 67 \mathrm{wt} \%$, $67.4 \mathrm{wt} \%$ and $74.2 \mathrm{wt} \%$ respectively (Table 4 ), and a strong peraluminous character (Figure 10(a)) as marked by high A/NK and A/CNK ratios above 1.7 and 1.55 respectively. The $\mathrm{SiO}_{2}$ content of the monazite-bearing dikes is slightly lower than that of porphyritic granites (Table 4). This low content is associated with the higher $\mathrm{Al}_{2} \mathrm{O}_{3}, \mathrm{CaO}$ and $\mathrm{Na}_{2} \mathrm{O}$ contents and a lower $\mathrm{K}_{2} \mathrm{O}$ content, leading to the higher $\mathrm{A} / \mathrm{NK}$ and $\mathrm{A} / \mathrm{CNK}$ ratios that corresponds to a more strongly peraluminous signature (Figure 10(a)). As suggested by its name, the dominant rock types within the Kovela granitic complex are tonalite, trondhjemite and granite. The dominantly tonalitic nature of the monazite-bearing dikes is illustrated on the normative Ab-An-Or ternary diagram (Figure 10(b)), with only few samples plotting in the granite field. They have higher $\mathrm{Na}_{2} \mathrm{O}$ content (4.3 to $8.0 \mathrm{wt} \%$ with average of $6.2 \mathrm{wt} \%)$, whereas $\mathrm{K}_{2} \mathrm{O}$ content $(0.8-3.6 \mathrm{wt} \%$ with average $1.5 \mathrm{wt} \%)$ is lower than the porphyritic granite samples. 

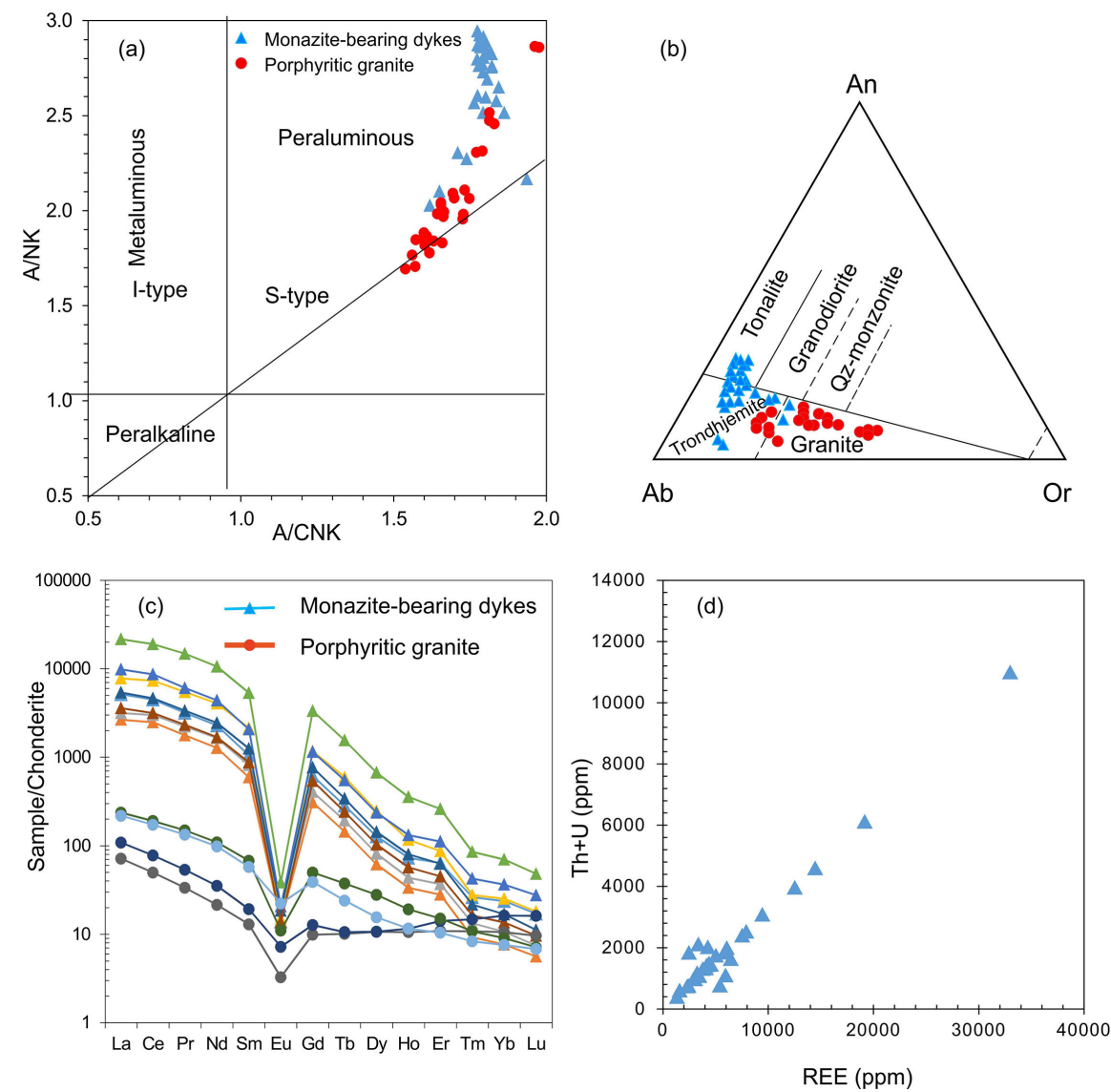

Figure 10. Whole rock geochemistry of the investigated porphyritic granite and monazite-bearing dikes from the Kovela granitic complex. (a) A/NK-A/CNK diagram [51], $\mathrm{A} / \mathrm{NK}=$ molar ratio of $\mathrm{Al}_{2} \mathrm{O}_{3} /\left[\mathrm{K}_{2} \mathrm{O}+\mathrm{Na}_{2} \mathrm{O}\right] ; \mathrm{A} / \mathrm{CNK}=$ molar ratio of $\mathrm{Al}_{2} \mathrm{O}_{3} /\left[\mathrm{CaO}+\mathrm{K}_{2} \mathrm{O}\right.$ $+\mathrm{Na}_{2} \mathrm{O}$; ; (b) An-Ab-Or diagram for monazite-bearing dikes and porphyritic granite samples [52] with fields from [53]; (c) Chondrite-normalized whole rock REE patterns for representative porphyritic granite and monazite-bearing dikes samples, the chondrite values are from [54]; (d) $U+T h(p p m)$ vs RREE (ppm) diagram showing the close relationship between an increase in REE and an increase in $U$ and Th for all the investigated monazite-bearing dikes samples.

Table 4. Representative major (wt\%) and trace elements including REE (ppm) compositions of the Monazite-bearing dikes and porphyritic granites in the Kovela granitic complex.

\begin{tabular}{ccccccccccccccc}
\hline Rock type & \multicolumn{4}{c}{ Mnz-bearing dikes } & \multicolumn{4}{c}{ Grt-bearing granite } & \multicolumn{3}{c}{ Bt-bearing granite } & \multicolumn{2}{c}{ Kfs-granite } \\
\hline Sample & $\mathrm{R} 3 / 2.0$ & $\mathrm{R} 3 / 4.0$ & $\mathrm{R} 7 / 3.5$ & $\mathrm{R} 8 / 17.5$ & $\mathrm{R} 14 / 3.8$ & $\mathrm{R} 12 / 7.0$ & $\mathrm{R} 2 / 54.0$ & $\mathrm{R} 9 / 30.0$ & $\mathrm{R} 16 / 4.10$ & $\mathrm{R} 16 / 7.1$ & $\mathrm{R} 16 / 9.1$ & $\mathrm{R} 7 / 5.5$ & $\mathrm{R} 8 / 5.5$ & $\mathrm{R} 9 / 8.0$ \\
\hline $\mathrm{Na}_{2} \mathrm{O}$ & 6.5 & 5.9 & 5.5 & 6.0 & 6.6 & 5.3 & 4.4 & 3.6 & 4.9 & 4.2 & 4.4 & 3.02 & 2.43 & 2.83 \\
$\mathrm{MgO}$ & 0.1 & 0.1 & 0.1 & 0.1 & 0.1 & 0.6 & 0.5 & 1.5 & 0.5 & 0.4 & 0.5 & 0.07 & 0.11 & 0.12 \\
$\mathrm{Al}_{2} \mathrm{O}_{3}$ & 21.3 & 20.0 & 18.7 & 19.4 & 22.3 & 18.3 & 17.7 & 15.5 & 17.7 & 17.2 & 17.7 & 14.9 & 14.2 & 14.8 \\
$\mathrm{SiO}_{2}$ & 64.6 & 59.8 & 66.7 & 66.8 & 59.2 & 65.6 & 67.0 & 68.3 & 67.0 & 68.1 & 67.0 & 73.9 & 74.9 & 73.8 \\
$\mathrm{P}_{2} \mathrm{O}_{5}$ & 0.4 & 2.3 & 0.3 & 0.7 & 1.6 & 0.1 & 0.1 & 0.1 & 0.1 & 0.1 & 0.1 & 0.05 & 0.05 & 0.07 \\
$\mathrm{~K}_{2} \mathrm{O}$ & 1.1 & 1.2 & 1.9 & 0.9 & 1.4 & 1.1 & 2.7 & 2.0 & 1.3 & 2.8 & 2.7 & 6.46 & 6.86 & 6.43 \\
$\mathrm{CaO}$ & 4.3 & 4.0 & 3.7 & 3.9 & 4.2 & 2.9 & 2.6 & 2.9 & 2.8 & 2.4 & 2.6 & 0.68 & 0.55 & 0.70 \\
\hline
\end{tabular}




\section{Continued}

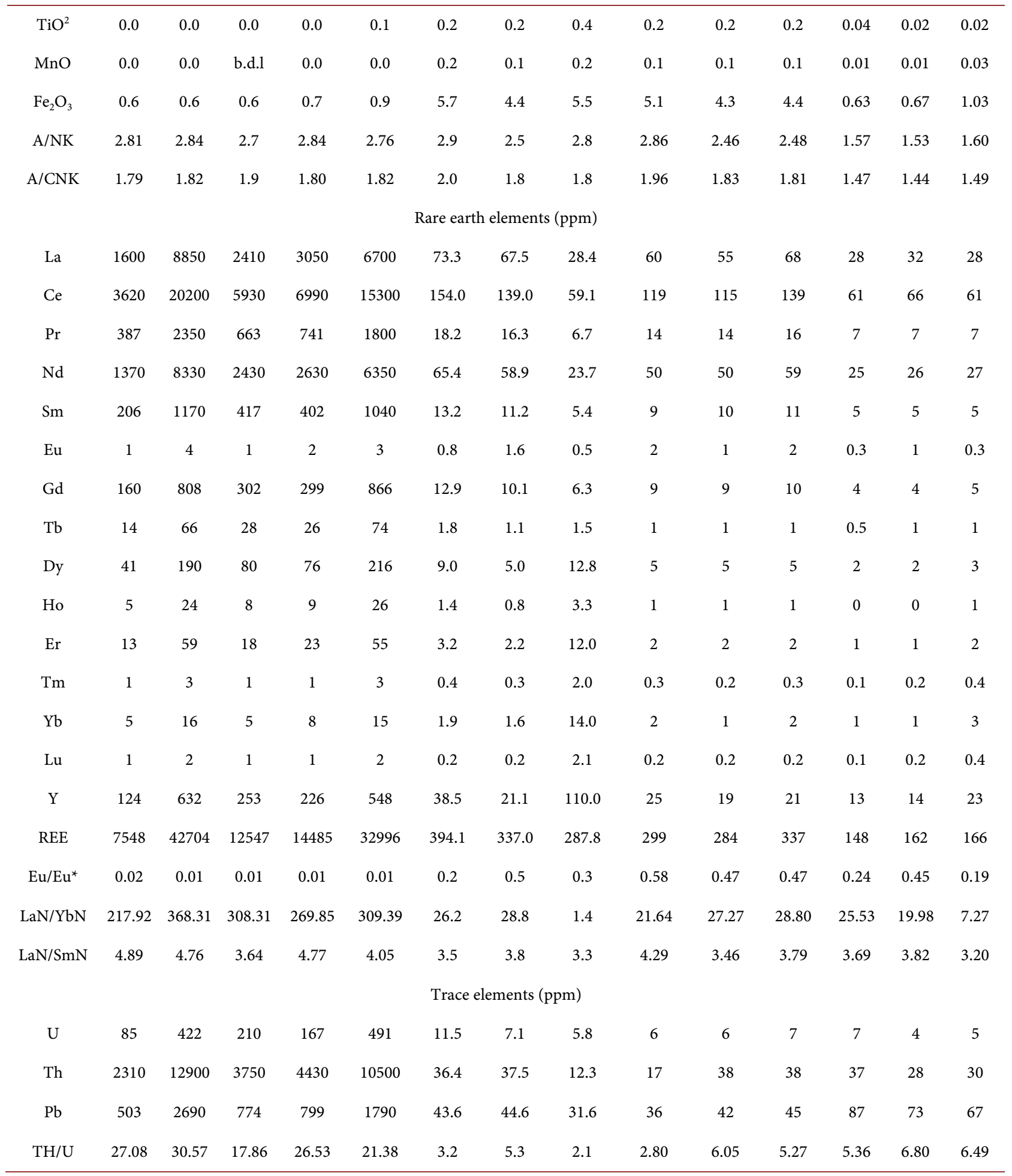

Slight difference in major element bulk-rock compositions among the monazite-bearing dikes and porphyritic granite types, whereas the significant enrichment of Th and REE in the monazite-bearing dikes are recognized. All the monazite-bearing samples display the highest REE content ranging from 2310 to 
12,900 ppm (Table 4). Their REE patterns are strongly fractionated in LREE over HREE (Figure $10(\mathrm{c})$ ), as evidenced by the $(\mathrm{La} / \mathrm{Yb})_{\mathrm{cn}}$ ratios ranging from 218 to 368 (Table 4), and more or less developed Eu negative anomaly (Figure 10 (b)), which intensity increases with the RREE content, as marked by decreasing Eu/Eu from 0.04 to 0.01 (Table 4). Samples of porphyritic granite have relatively low total REE concentrations (50 - $337 \mathrm{ppm}$ ), low Th content (weakly radioactive) and almost flat chondrite normalised REE diagrams, with $(\mathrm{La} / \mathrm{Yb})_{\mathrm{cn}}$ ratios of $3.15-28.8$ and negative $\mathrm{Eu}$ anomalies $\left(\mathrm{Eu} / \mathrm{Eu}^{*}=0.1-0.60\right.$; Figure 10(c), Table 4). The monazite-bearing dikes contain the highest Th and U with average of 2300 and $96 \mathrm{ppm}$ respectively, and enrichment of these actinides rapidly increases with $\Sigma$ REE (Figure 10(d)). The whole-rock analyses suggest that most, if not all, REE and Th in the monazite-bearing dikes is contained in monazite. The monazite-bearing dikes are characterized by higher $\mathrm{Th} / \mathrm{U}$ ratios than their host porphyritic granite rocks. The Th/ $\mathrm{U}$ ratio of the monazite-bearing varies from 17.9 to 30.6 with average of 24.7 , while the host porphyritic granites seem to have significantly lower $\mathrm{Th} / \mathrm{U}$ ratios $(\mathrm{Th} / \mathrm{U}=2.1$ to 6.8 ; average 4.8 ), and indicate a separate magmatic source than those of monazite-bearing dikes. This enrichment in $\mathrm{Th} / \mathrm{U}$ ratio of bulk rock composition correlates with its $\mathrm{Th} / \mathrm{U}$ ratio in monazite grains. Several factors affecting the $\mathrm{Th} / \mathrm{U}$ ratio are investigated, including the bulk rock concentrations of Th and $\mathrm{U}$, the amount of Th-rich monazite in the host rocks, and the composition of the original magma. Incorporation of Th and $\mathrm{U}$ into monazite is governed mainly by the huttonite and cheralite substitutions, respectively. Taken together, our results suggest that the monazite is primarily responsible for the distributions of REEs, Th, and $U$ among the monazite-bearing dikes, and that the monazite can be assigned to composition of monazite-huttonite/thorite solid solution, that formed at an early stage of igneous crystallization.

\section{Geochronology}

The monazite crystals from each sample exhibit several complex types of zoning evident in backscattered electron (BSE) images (Figure 11). Based on the BSE images (Figure 3, Figure 5 and Figure 11), the internal structures of the grains were classified into core-rim structure as oscillatory concentric, sector and intergrowth-like zoning structure and zones texturally appear to overprint pre-existing zoning. Age calculations and concordia plots were done using Isoplot (version 3.75, [55]). Individual analyses are presented with $2 \sigma$ error in concordia diagrams, and uncertainties in mean age calculations are quoted at the 95\% level $(2 \sigma)$. The complete LA-ICP-MS analytical data for dated monazites from the Kovela granitic complex are given in the Supplementary data Table 4. Three samples (R3/4.40, R4/29.30 and R8/18.50) were selected for U-Pb dating. BSE images and X-ray maps of monazite from the studied samples show the location of ICPMS laser ablation pits $(10 \mu \mathrm{m})$ and their corresponding ${ }^{207} \mathrm{~Pb} /{ }^{206} \mathrm{~Pb}$ ages $(2 \sigma$ level). 

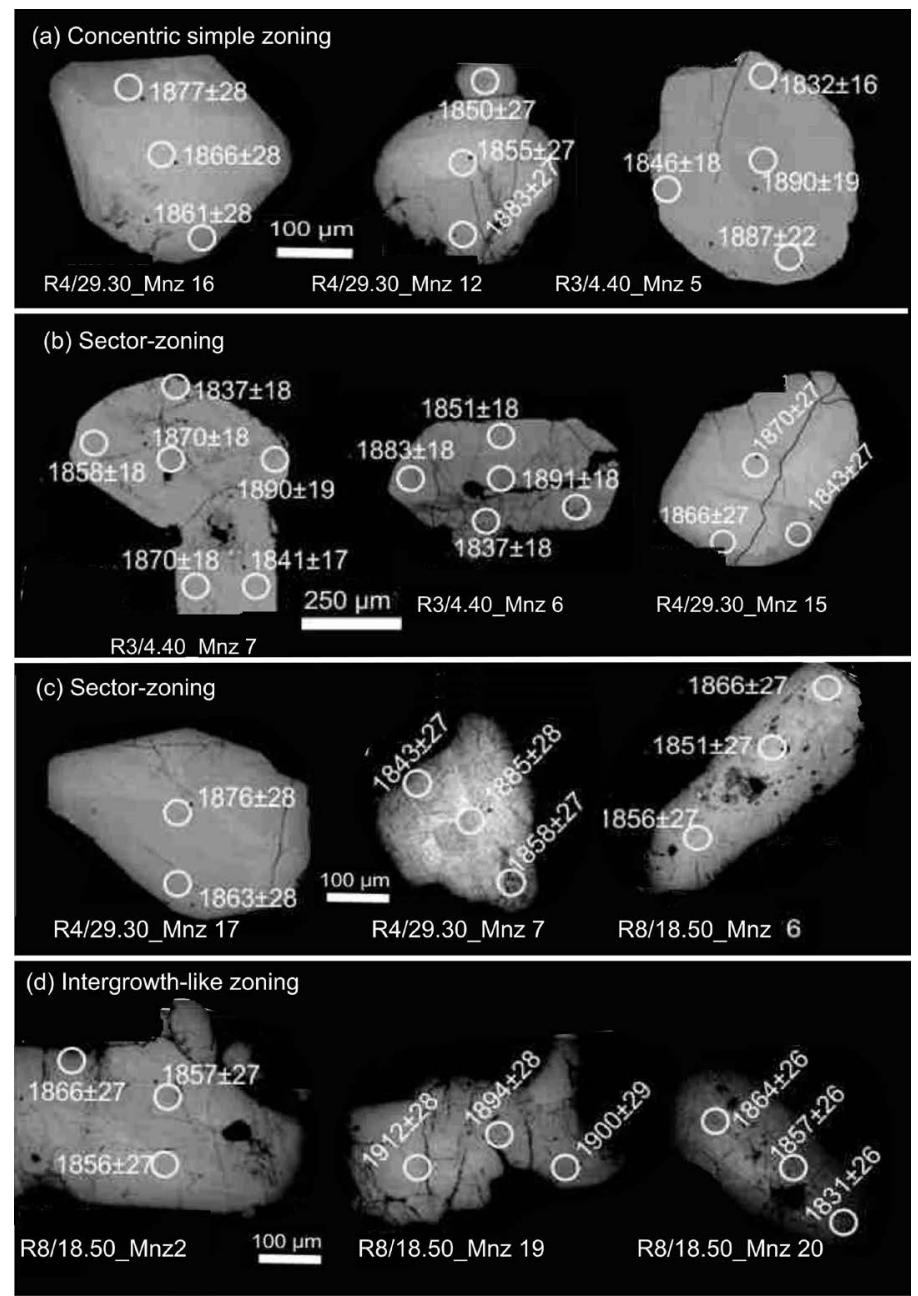

Figure 11. BSE images of monazite grains with spot ${ }^{207} \mathrm{~Pb} /{ }^{206} \mathrm{~Pb}$ ages from Kovela granitic complex; (a) concentric simple zoning with spot ages; (b, c) sector zoning sample with spot ages; (d) intergrowth like zoning with spot ages.

A total of 44 points were measured from five monazite grains in sample $\mathrm{R} 3 / 4.4$, and were analyzed from the core, mantle and rim regions (Supplementary data Table 4). Grains are oval to round in shape, mostly oscillatory- and sector-zoned, and are about $350 \mu \mathrm{m}$ in length and $100 \mu \mathrm{m}$ in width (Figure 5 and Figure 11). The spot dates vary from $1796 \pm 16$ to $1891 \pm 18$ Ma. Thirty-eight spot analysis provide a younger concordia age of $1833.4 \pm 4.9 \mathrm{Ma}$ $(\mathrm{MSWD}=1.8$, probability $=0.18$; Figure $12(\mathrm{a}))$ and a weighted mean ${ }^{207} \mathrm{~Pb} /{ }^{206} \mathrm{~Pb}$ age of $1832.6 \pm 6.3$ (95\% confidence limit, MSWD = 4.8; Figure 12(b)), which is consistent with most ${ }^{207} \mathrm{~Pb} /{ }^{206} \mathrm{~Pb}$ ages. Six-spot analysis determinations gave an oldest Concordia age of $1885 \pm 13 \mathrm{Ma}$ (MSWD $=0.91$, Probability $=0.34$; Figure $12(\mathrm{c})$ ) and a weighted mean ${ }^{207} \mathrm{~Pb} /{ }^{206} \mathrm{~Pb}$ age of $1888.1 \pm 7.6 \mathrm{Ma}$ (95\% confidence limit, MSWD $=0.13$, probability $=0.99$; Figure $12(\mathrm{~d})$ ). The $\mathrm{U}$ and Th contents from analyzed spots vary widely from 40,559 to $112,398 \mathrm{ppm}$ and from 16.4 to $19.6 \mathrm{wt} \% \mathrm{ThO}_{2}$, respectively (Supplementary data Table 5). The Th/U ratio ranges between 15 and 29 , and the $\mathrm{Th} / \mathrm{U}$ v. age plots $\left({ }^{207} \mathrm{~Pb} /{ }^{206} \mathrm{~Pb}\right.$ near-concordant age) 
display a weak negative correlation (Figure 13(e)).

Twenty-nine spots were analyzed from 5 monazite grains from sample R4/29.30. Most of the grains are subhedral, showing irregular and sector zoning (a few grains also have oscillatory zoning) with a very thin overgrowth along the rim (Figure 11). The grains are approximately $300 \mu \mathrm{m}$ in length and approximately $100 \mu \mathrm{m}$ in width. The plot of all the data shows a spread along the concordia line (Figure $12(\mathrm{e})$ ). The spots yield ${ }^{207} \mathrm{~Pb} /{ }^{206} \mathrm{~Pb}$ dates of $1858.0 \pm 9.5 \mathrm{Ma}$ $(\mathrm{MSWD}=1.2$, probability $=0.26$; Figure $12(\mathrm{e}))$. The weighted average of ${ }^{207} \mathrm{~Pb} /{ }^{206} \mathrm{~Pb}$ mean ages from an overgrowth monazite domain yields $1860.4 \pm 5.1$ $\mathrm{Ma}(\mathrm{MSWD}=1.3$, probability $=0.12$; Figure $12(\mathrm{f}))$. The $\mathrm{U}$ and Th contents vary from 22,263 to $77,256 \mathrm{ppm}$ and from 11.5 to $19.2 \mathrm{wt} \% \mathrm{ThO}_{2}$, respectively. $\mathrm{Th} / \mathrm{U}$ v. ages $\left({ }^{207} \mathrm{~Pb} /{ }^{206} \mathrm{~Pb}\right)$ are plotted in Figure $\left.13(\mathrm{e})\right)$ and display an inverse correlation.
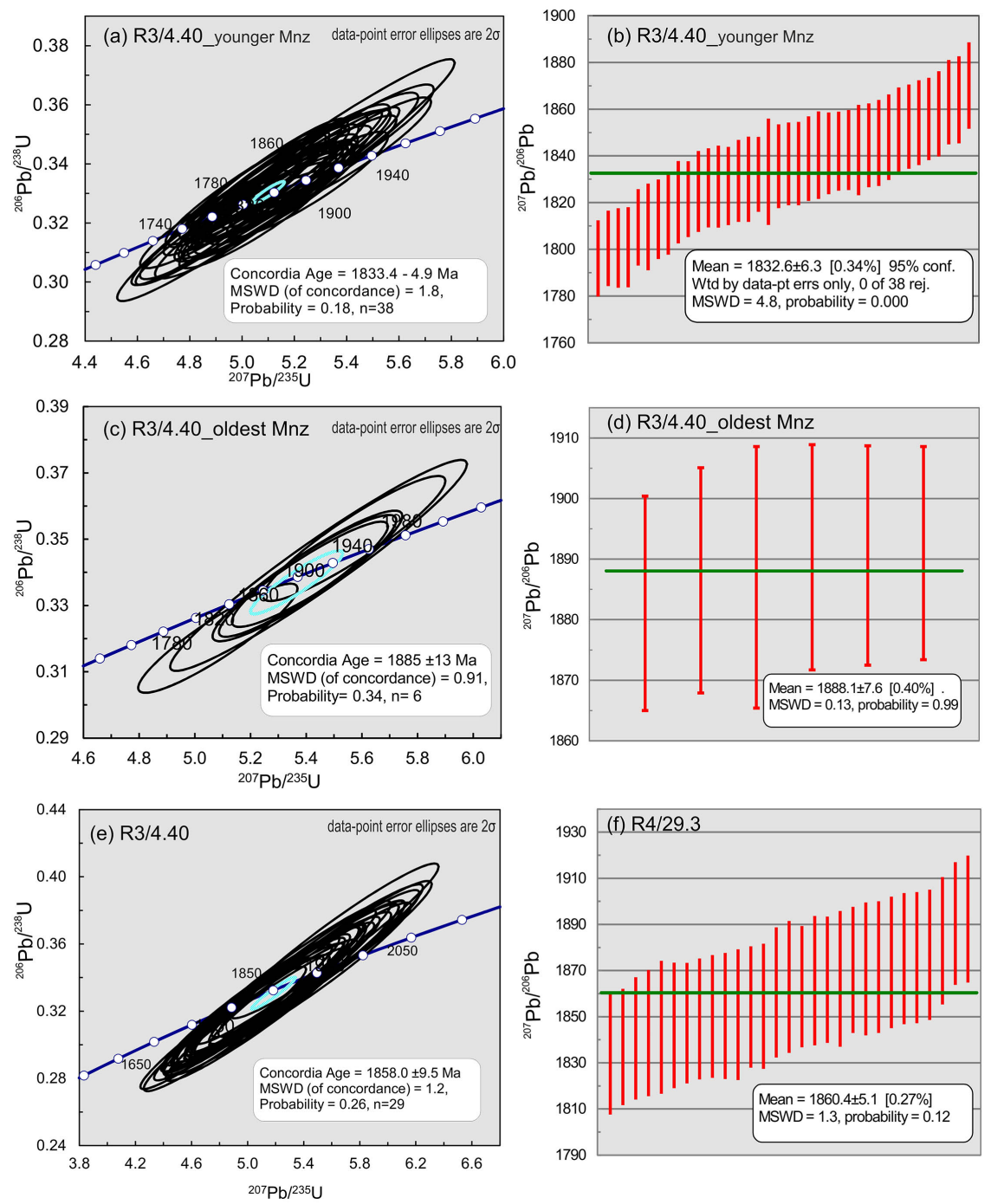

Figure 12. U-Th-total $\mathrm{Pb}$ concordia diagrams for monazite data (with error bars) and the calculated weighted mean ${ }^{207} \mathrm{~Pb} /{ }^{206} \mathrm{~Pb}$ age of monazite-(Ce) from the samples $\mathrm{R} 3 / 4.40$ (a-d) and R4/29.30 (e-f), using the Isoplot/Ex program of [55]. 

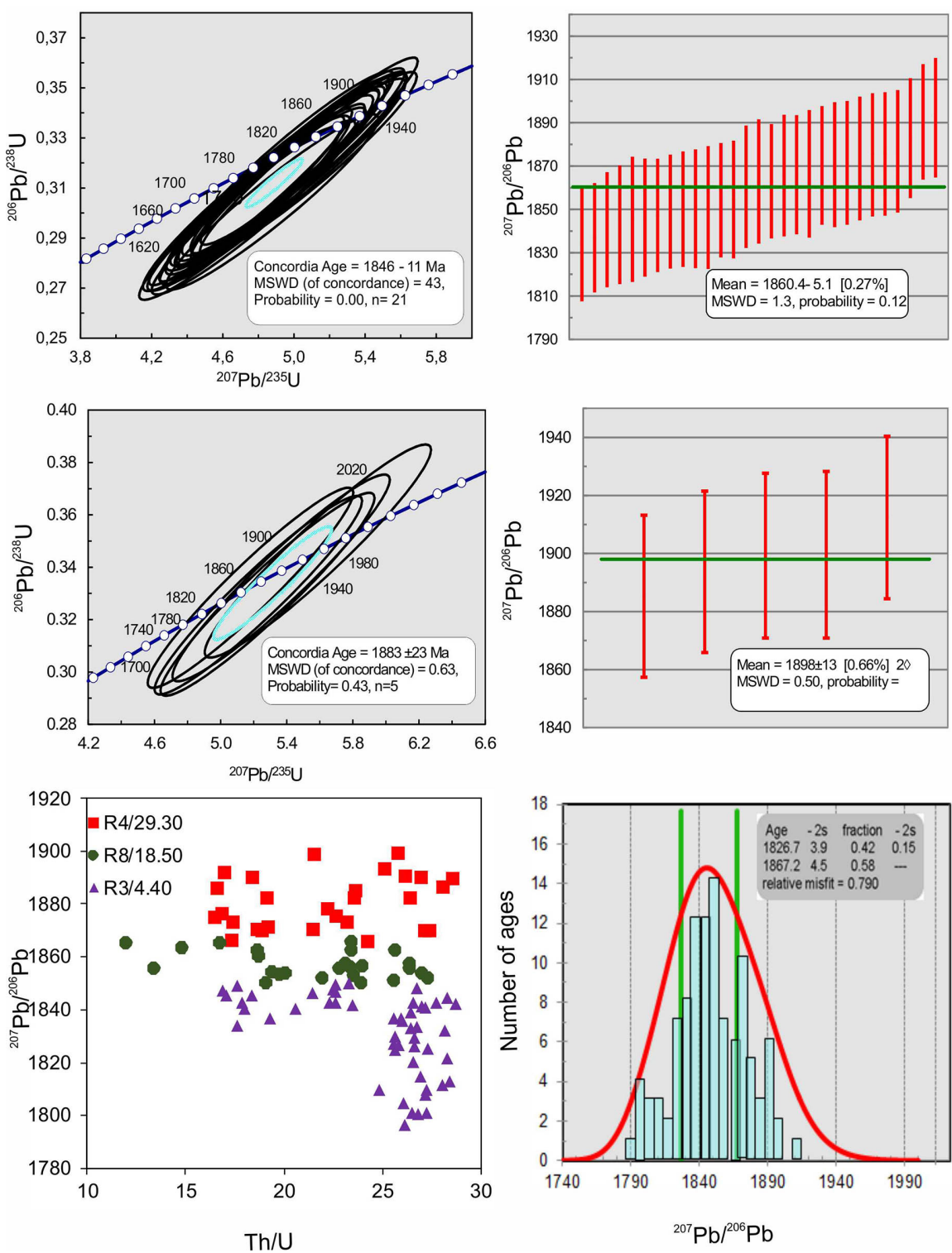

Figure 13. (a-d) U-Th-total $\mathrm{Pb}$ concordia diagrams for monazite data (with error bars) and the calculated weighted mean ${ }^{207} \mathrm{~Pb} /{ }^{206} \mathrm{~Pb}$ age of monazite- $(\mathrm{Ce})$ from the samples R8/18.50, using the Isoplot/Ex program [55]; (e) U/Th values, determined by ICP-MS, plotted versus age for $\mathrm{Th}-\mathrm{Pb}$ monazite ages determined in samples $\mathrm{R} 3 / 4.40$ and $\mathrm{R} 4 / 29.30$ respectively; (f) Probability-density plots of monazite ages in Kovela granitic complex. Population ages and $2 \sigma$ errors are in Ma. Monazite analyses and mean ${ }^{207} \mathrm{~Pb} /{ }^{206} \mathrm{~Pb}$ ages.

Twenty-six points from 8 monazite grains were measured from R8/18.50 sample. All the grains are euhedral to subhedral in shape, with grains size ranging from $100 \times 50 \mu \mathrm{m}$ to $450 \times 1000 \mu \mathrm{m}$ (Figure 11). Most of the grains are homogeneous, although few contain a core-rim structure. In such grains, the irregular to oscillatory-zoned core is surrounded by either oscillatory-zoned or homogenous overgrowth (Figure 11(d)). The majority of the analyzed data are distributed along the concordia line, clustering near the lower intercept (Figure 13(a)). The dominant concordia age recorded from this sample is $1846 \pm 11 \mathrm{Ma}$ 
$($ MSWD $=43$, probability $=0.0, \mathrm{n}=21$; Figure $13(\mathrm{a}))$, whereas the oldest spots date is $1883 \pm 23 \mathrm{Ma}(\mathrm{MSWD}=0.63$, probability $=0.43, \mathrm{n}=5$; Figure $13(\mathrm{c})$ ). The younger monazite grains yielded a weighted mean date of $1856.9 \pm 6.0 \mathrm{Ma}$ $($ MSWD $=0.71$, probability $=0.82$; Figure $13(\mathrm{~b}))$, whereas the oldest grains yield a weighted mean date of $1898 \pm 13 \mathrm{Ma}(\mathrm{MSWD}=0.50$, probability $=0.74$; Figure 13(d)).

A relative probability density plots based on 100 spot ages from three samples are presented in Figure 13(f). Most of the ages concentrated between $1830 \pm 4$ $\mathrm{Ma}$ and $1870 \pm 4.5 \mathrm{Ma}$, with few ages fall into two groups, 1795 - $1830 \mathrm{Ma}$ and 1870 - $1900 \mathrm{Ma}$, and only one age older than $1910 \mathrm{Ma}$. Monazite dates from all samples are equivalent with a weighted mean of $1850 \pm 5$ (95\% confidence limit, MSWD $=6.4$ ), suggest that the crystallization age of the monazite-bearing dikes are interpreted from the monazite date of $1.85 \mathrm{Ga}$. Thorium has been shown in a number of studies to be indicative of the timing of monazite growth and age determinations particularly for high Th monazite [56]. In this study, Th reveals little about the possible causes of the observed age trends. There is a small but systematic difference in Th/U ratios: the 1830 - $1870 \mathrm{Ma}$ concordant monazites have a mean $\mathrm{Th} / \mathrm{U}$ ratio of 22 and the 1870 - $1900 \mathrm{Ma}$ concordant monazites have a mean $\mathrm{Th} / \mathrm{U}$ ratio of 21.9. The younger group 1795 - $1830 \mathrm{Ma}$ has a much greater $\mathrm{Th} / \mathrm{U}$ ratio with an average of 27.

\section{Geothermobarometry}

\subsection{Mineral Chemistry}

As described in petrography; the studied sample rocks contain large porphyroblasts of garnet and cordierite and the matrix minerals including plagioclase, quartz, K-feldspar, biotite, sillimanite and chlorite (Figure 2). Garnet porphyroblast $(0.2-0.5 \mathrm{~cm})$ are surrounded by coarse-grained biotite and sillimanite (Figure 14(a) and Figure 14(b)). A small amount of rounded quartz, zircon and monazite grains were observed as inclusions in garnet. The majority of the alkali feldspar fail between the sanidine and orthoclase series, consisting of intergrowths of monoclinic K-feldspar, anorthoclase and sodium-rich plagioclase. Representative compositions of minerals in the analysed samples are given in Table 5 .

In Sample R3/4.40, two zoning profiles are determined in Grn 1 and Grn 2. The profile in microdomain Grn1 shows slight chemical zoning: from the core to the rim (Figure 14(a) and Figure 14(c)). Garnet porphyroblasts displayed a rim ward increase in almandine content (77.8 - $83.6 \mathrm{~mol} \%$ ), and a gradual decrease in pyrope (from 13.0 to $7.6 \mathrm{~mol}$ \%), grossularite (from 5.2 to 2.9 mol.\%) and the content of spessartine slightly increases (from 4.4 to $5.8 \mathrm{~mol} \%$ ). The $\mathrm{Fe} /(\mathrm{Fe}+\mathrm{Mg})$ values of garnet are relatively constant $(0.86-0.92)$ (Table 4; Figure 14(c)). In microdomain Grn 2, from the core to the mantle, the contents of almandine increases from $80.4 \%$ to $83.2 \%$ and pyrope decreases from $10.9 \%$ to $7.4 \%$ respectively, whereas the spessartine content increases from $4.6 \%$ to 
$6.4 \%$ and the content of grossularite slightly decreases from 4.0 to 3.0 (Table 4 ). In Sample R5/27.10, the microdomain Grn1 profile in the porphyroblastic garnet (Figure $14(\mathrm{~b})$ ) is characterized by an increase of almandine $(76.4 \%-81.5 \%)$ and a decrease of pyrope $(17.3 \%-9.5 \%)$ from the core to the rim, while the spessartine $(3.6 \%-5.9 \%)$ and grossularite $(2.5 \%-3.0 \%)$ contents are almost homogeneous (Figure 14(d)). All the garnets are mainly a almandine-pyrope solid solution, with varying amounts of spessartine $\left(\mathrm{Mn}^{2+}\right)$, and grossularite $\left(\mathrm{Ca}^{2+}\right)$ structural units/end-members substituting in the crystal lattices. The garnet zoning, characterized by an increasing of $\mathrm{Mg}$ and $\mathrm{Ca}$ in the core and a decreasing of $\mathrm{Mn}$ and Fe toward the borders, implies a prograde metamorphism. The $\mathrm{Mg}$ and $\mathrm{Ca}$-rich core zone mentioned above is characterized by slight increase in the pyrope and grossular contents respectively, while the garnet porphyroblasts displayed a rim ward increase in almandine and spessartine contents.
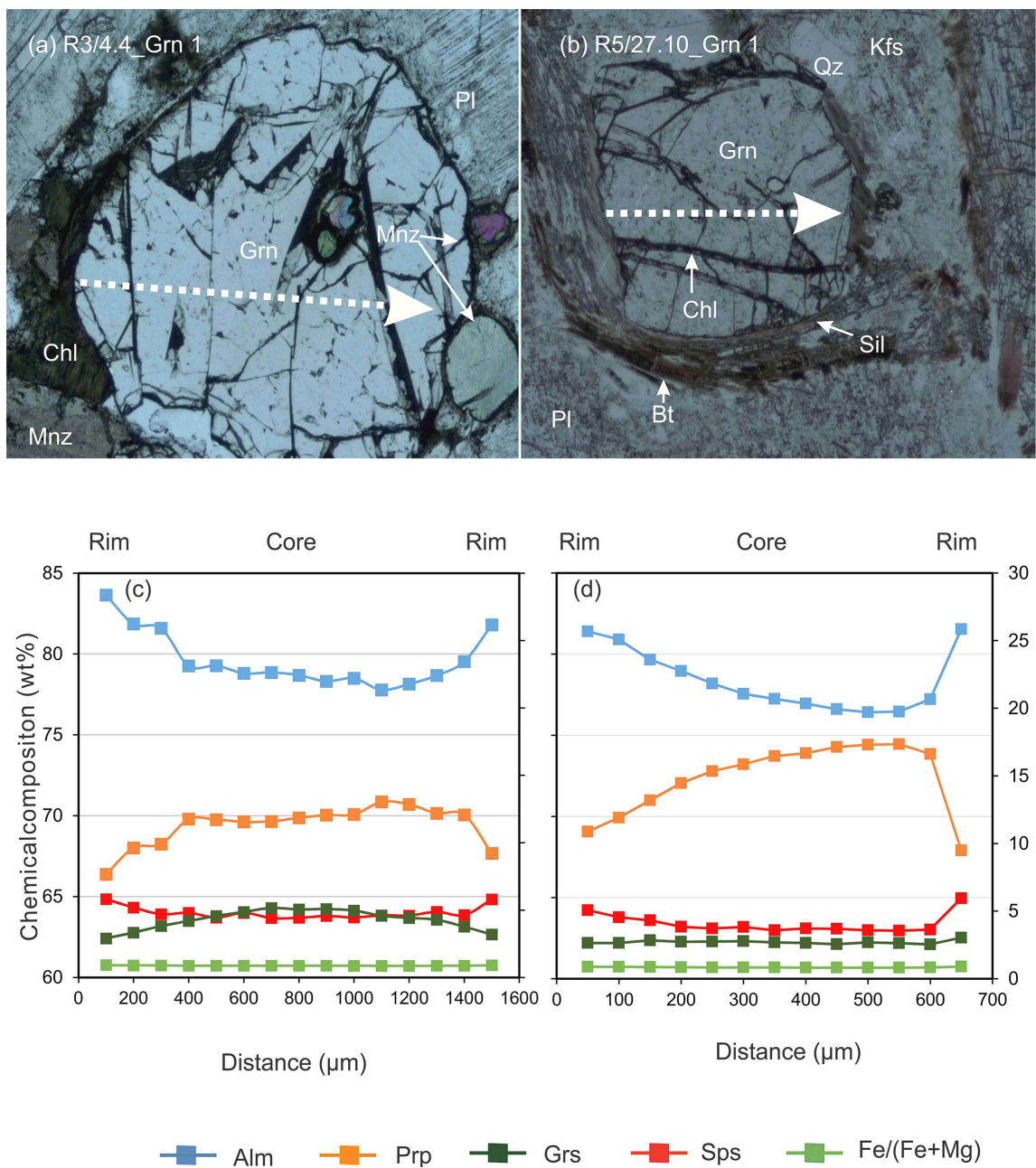

Figure 14. (a, b) Garnet porphyroblast from the samples R3/4.40 and R5/27.50 showing the analysed profile (15 and 13 points respectively; rim-core-rim); (c, d) Garnet zonation in almandine (Alm) (left axis) and pyrope (Prp)-grossular (Grs)-spessartine (Sps) (right axis) contents (\% end member) diagram. 
Table 5. Representative electron microprobe analyses of minerals DISCUSSED in this studY; cations normalized to $12 \mathrm{O}$ (Grn), 22 $\mathrm{O}(\mathrm{Bt})$ and $8 \mathrm{O}(\mathrm{Pl})$. (Alm = almandine; $\mathrm{Prp}=$ pyrope; $\mathrm{Sps}=$ spessartine; Grs = grossular; $\mathrm{An}=$ anorthite; $\mathrm{Ab}=$ albite; $\mathrm{Kfs}=$ K-feldspar).

\begin{tabular}{cccccccccccccc}
\hline Sample & \multicolumn{2}{c}{ R3/4.40_Grn 1 } & \multicolumn{2}{c}{ R3/4.40_Grn 2 } & \multicolumn{2}{c}{ R3/4.40_Grn 3 } & \multicolumn{2}{c}{ R5/27.10_Grn 1 } & \multicolumn{2}{c}{ R9/30.10_Grn 1 } & \multicolumn{2}{c}{ R9/30.10_Grn 2 } \\
\hline Garnet & core & Rim & core & Rim & core & Rim & core & Rim & core & Rim & core & Rim \\
\hline Si & 2.96 & 2.99 & 2.97 & 2.94 & 2.99 & 2.97 & 2.94 & 2.95 & 2.94 & 2.96 & 2.94 & 2.96 \\
Al iv & 0.04 & 0.01 & 0.03 & 0.06 & 0.01 & 0.03 & 0.06 & 0.05 & 0.06 & 0.04 & 0.06 & 0.04 \\
Al vi & 1.95 & 2.00 & 1.96 & 1.96 & 1.99 & 1.97 & 1.95 & 1.95 & 1.94 & 1.95 & 1.95 & 1.94 \\
Fe3+ & 0.04 & 0.00 & 0.03 & 0.04 & 0.01 & 0.02 & 0.04 & 0.04 & 0.05 & 0.04 & 0.04 & 0.05 \\
Fe2+ & 2.40 & 2.51 & 2.44 & 2.53 & 2.44 & 2.53 & 2.35 & 2.48 & 2.45 & 2.50 & 2.32 & 2.48 \\
Fe tot & 2.43 & 2.51 & 2.47 & 2.57 & 2.45 & 2.56 & 2.39 & 2.53 & 2.50 & 2.54 & 2.36 & 2.53 \\
Mn & 0.13 & 0.17 & 0.14 & 0.19 & 0.14 & 0.17 & 0.11 & 0.18 & 0.14 & 0.18 & 0.13 & 0.16 \\
Mg & 0.35 & 0.23 & 0.32 & 0.24 & 0.34 & 0.23 & 0.50 & 0.28 & 0.37 & 0.27 & 0.50 & 0.32 \\
Ca & 0.15 & 0.09 & 0.11 & 0.09 & 0.09 & 0.09 & 0.08 & 0.09 & 0.08 & 0.08 & 0.09 & 0.07 \\
Total & 8.03 & 8.01 & 8.02 & 8.04 & 8.00 & 8.02 & 8.03 & 8.03 & 8.04 & 8.03 & 8.04 & 8.03 \\
Alm & 79.14 & 83.71 & 80.74 & 83.17 & 81.33 & 83.86 & 77.35 & 82.04 & 80.63 & 82.59 & 76.40 & 81.83 \\
Prp & 11.59 & 7.61 & 10.75 & 7.79 & 11.20 & 7.47 & 16.60 & 9.22 & 12.08 & 8.92 & 16.43 & 10.47 \\
Sps & 4.33 & 5.79 & 4.73 & 6.17 & 4.57 & 5.78 & 3.58 & 5.78 & 4.52 & 5.92 & 4.21 & 5.31 \\
Grs & 4.94 & 2.89 & 3.78 & 2.86 & 2.90 & 2.89 & 2.48 & 2.96 & 2.77 & 2.57 & 2.96 & 2.38
\end{tabular}

Biotite R3/4.40_Bt1 R3/4.40_Bt2 R3/4.40_Bt3 R3/4.40_Bt4 R3/4.40_Bt5 R3/4.40_Bt6 R5/27.10_Bt1 R5/27.10_Bt2 R9/30.10_Bt1 R9/30.10_Bt2 R9/30.10_Bt3 R9/30.10_Bt4

\begin{tabular}{|c|c|c|c|c|c|c|c|c|c|c|c|c|}
\hline $\mathrm{Si}$ & 5.26 & 5.22 & 5.28 & 5.26 & 5.31 & 5.27 & 5.27 & 5.27 & 5.16 & 5.25 & 5.25 & 5.25 \\
\hline $\mathrm{Al}$ iv & 2.74 & 2.78 & 2.72 & 2.74 & 2.69 & 2.73 & 2.73 & 2.73 & 2.84 & 2.75 & 2.75 & 2.75 \\
\hline $\mathrm{Al}$ vi & 1.02 & 1.01 & 0.98 & 1.02 & 0.95 & 0.96 & 1.02 & 0.99 & 0.97 & 0.99 & 0.94 & 0.97 \\
\hline $\mathrm{Ti}$ & 0.19 & 0.19 & 0.18 & 0.17 & 0.18 & 0.19 & 0.18 & 0.17 & 0.16 & 0.18 & 0.19 & 0.18 \\
\hline $\mathrm{Fe}$ & 2.92 & 2.98 & 2.99 & 3.01 & 2.96 & 2.99 & 2.99 & 3.05 & 3.06 & 3.07 & 3.08 & 3.01 \\
\hline $\mathrm{Mn}$ & 0.01 & 0.01 & 0.01 & 0.01 & 0.01 & 0.01 & 0.01 & 0.01 & 0.02 & 0.01 & 0.01 & 0.01 \\
\hline $\mathrm{Mg}$ & 1.48 & 1.51 & 1.47 & 1.46 & 1.51 & 1.51 & 1.43 & 1.47 & 1.62 & 1.47 & 1.50 & 1.50 \\
\hline $\mathrm{K}$ & 1.89 & 1.94 & 1.88 & 1.89 & 1.90 & 1.87 & 1.86 & 1.92 & 1.78 & 1.88 & 1.94 & 1.93 \\
\hline Total & 15.51 & 15.64 & 15.51 & 15.55 & 15.51 & 15.52 & 15.49 & 15.61 & 15.63 & 15.60 & 15.66 & 15.60 \\
\hline
\end{tabular}

Plagioclase R3/4.40_Pl1 R3/4.40_Pl2 R3/4.40_Pl3 R3/4.40_Pl4 R3/4.40_Pl5 R3/4.40_Pl6 R5/27.10_Pl1 R5/27.10_Pl2 R9/30.10_Pl1 R9/30.10_Pl2 R9/30.10_Pl3 R9/30.10_Pl4

\begin{tabular}{cccccccccccccc}
$\mathrm{Si}$ & 2.45 & 2.45 & 2.49 & 2.46 & 2.49 & 2.45 & 2.48 & 2.43 & 2.49 & 2.50 & 2.50 & 2.49 \\
$\mathrm{Al}$ & 1.26 & 1.27 & 1.25 & 1.28 & 1.26 & 1.27 & 1.25 & 1.30 & 1.24 & 1.24 & 1.22 & 1.23 \\
$\mathrm{Ca}$ & 0.45 & 0.46 & 0.41 & 0.46 & 0.42 & 0.47 & 0.43 & 0.49 & 0.40 & 0.39 & 0.39 & 0.40 \\
$\mathrm{Na}$ & 1.38 & 1.33 & 1.38 & 1.32 & 1.38 & 1.31 & 1.36 & 1.29 & 1.42 & 1.41 & 1.41 & 1.43 \\
$\mathrm{~K}$ & 0.06 & 0.04 & 0.04 & 0.02 & 0.02 & 0.06 & 0.03 & 0.03 & 0.03 & 0.03 & 0.03 & 0.03 \\
$\mathrm{Total}$ & 5.65 & 5.62 & 5.61 & 5.58 & 5.59 & 5.60 & 5.59 & 5.59 & 5.63 & 5.62 & 5.62 & 5.64 \\
$\mathrm{Ab}$ & 73.02 & 72.34 & 75.40 & 73.30 & 75.82 & 71.34 & 74.73 & 71.32 & 76.93 & 77.25 & 76.93 & 76.92 \\
$\mathrm{An}$ & 23.77 & 25.24 & 22.17 & 25.41 & 22.85 & 25.65 & 23.69 & 27.13 & 21.41 & 21.24 & 21.32 & 21.39 \\
$\mathrm{Kfs}$ & 3.21 & 2.42 & 2.43 & 1.29 & 1.33 & 3.01 & 1.58 & 1.55 & 1.67 & 1.51 & 1.76 & 1.70 \\
\hline
\end{tabular}




\subsection{P-T Paths and Conditions}

The temperatures for garnet core and rim growth were calculated using garnet-biotite thermometer [17], giving temperature of $712^{\circ} \mathrm{C}-611^{\circ} \mathrm{C}, 698^{\circ} \mathrm{C}$ $622^{\circ} \mathrm{C}$ and $694^{\circ} \mathrm{C}-604^{\circ} \mathrm{C}$ for sample $\mathrm{R} 3 / 4.40 ; 759^{\circ} \mathrm{C}-690^{\circ} \mathrm{C}$ and $824^{\circ} \mathrm{C}-678^{\circ} \mathrm{C}$ for sample $\mathrm{R} 9 / 30.10 ; 811^{\circ} \mathrm{C}-658^{\circ} \mathrm{C}$ for sample $\mathrm{R} 5 / 27.10$ respectively. Pressure was estimated by the garnet + plagioclase + biotite + quartz barometer (GBPQ) after $\mathrm{Wu}$ et al. [57], yielding values of 2.8 - $5.8 \mathrm{kbar}, 2.7-4.8 \mathrm{kbar}$ and 2.6 - 3.7 kbar (sample R3/4.40); 2.9 - 4.3 kbar and 3.0 - 4.4 kbar (sample R9/30.0); 2.7 $3.4 \mathrm{kbar}$ (sample $\mathrm{R} 5 / 27.10$ ) respectively at $720^{\circ} \mathrm{C}$. The inherent absolute errors of the GB geothermometer and GBPQ geobarometer are estimated to be $25^{\circ} \mathrm{C}$ [17] and $0.8 \mathrm{kbar}$ [58] respectively. A summary of the calculated temperatures and pressures are presented in Table 5 and a corresponding P-T graph is used to show a pictorial representation of the P-T distribution for the rocks of the study area (Figure 15). The P-T estimates are listed in Table 6. The experimental calibration for garnet-biotite thermometer $\left(\mathrm{T}_{\mathrm{Bh}}\right)$ by Bhattacharya et al. [18] with the Mg-model and Fe-model GMPQ barometers by Hoisch [19], yields temperature estimates slightly lower than those ob-tained with the calibration of GB thermometer [17] and GBPQ barometer [57], (maxi-mum differences $-30^{\circ} \mathrm{C}-100^{\circ} \mathrm{C}$ ).

Equilibrium phase diagrams using the analyzed bulk rock compositions were calculated in the Thermo-Calc Software System THERMOCALC using Perple X 6.8.0 software [59] [60] (http://www.Perple_X.ethz.ch), with the Holland \& Powell [61] database (hp11ver.dat). The analyzed bulk rock compositions were determined at Labtium laboratories by X-ray fluorescence analysis (XRF) on the drill core sample R3/4.40 pulp from the same sample used for preparing thin section. The estimated protolith compositions for representative samples are

Table 6. Calculated P-T conditions for porphyritic granite type within Kovela granitic complex.

\begin{tabular}{|c|c|c|c|c|c|}
\hline Sample & Grn & $\mathrm{T}(\mathrm{GB})_{\mathrm{Ho}}\left({ }^{\circ} \mathrm{C}\right)$ & $\mathrm{P}(\mathrm{GHPQ})_{\mathrm{Wu}}(\mathrm{Kbar})$ & $\mathrm{T}_{\mathrm{Bh}}\left({ }^{\circ} \mathrm{C}\right)$ & $\mathrm{P}_{\mathrm{H} 90}($ Kbar $)$ \\
\hline \multirow{2}{*}{ R3/4.40_Grn 1} & core & 712 & 5.8 & 663 & 6.0 \\
\hline & Rim & 611 & 2.8 & 549 & 2.2 \\
\hline \multirow{2}{*}{ R3/4.40_Grn 2} & core & 698 & 4.8 & 647 & 4.9 \\
\hline & Rim & 622 & 2.7 & 562 & 2.4 \\
\hline \multirow{2}{*}{ R3/4.40_Grn 3} & core & 694 & 3.7 & 639 & 3.9 \\
\hline & Rim & 604 & 2.6 & 541 & 2.1 \\
\hline \multirow{2}{*}{ R5/27.10_Grn 1} & core & 811 & 3.4 & 796 & 4.8 \\
\hline & Rim & 658 & 2.7 & 608 & 2.8 \\
\hline \multirow{2}{*}{ R9/30.10_Grn 1} & core & 759 & 4.3 & 652 & 4.1 \\
\hline & Rim & 690 & 2.9 & 600 & 3.1 \\
\hline \multirow{2}{*}{ R9/30.10_Grn 2} & core & 824 & 4.4 & 787 & 5.7 \\
\hline & Rim & 678 & 3.0 & 631 & 3.3 \\
\hline
\end{tabular}


(a)
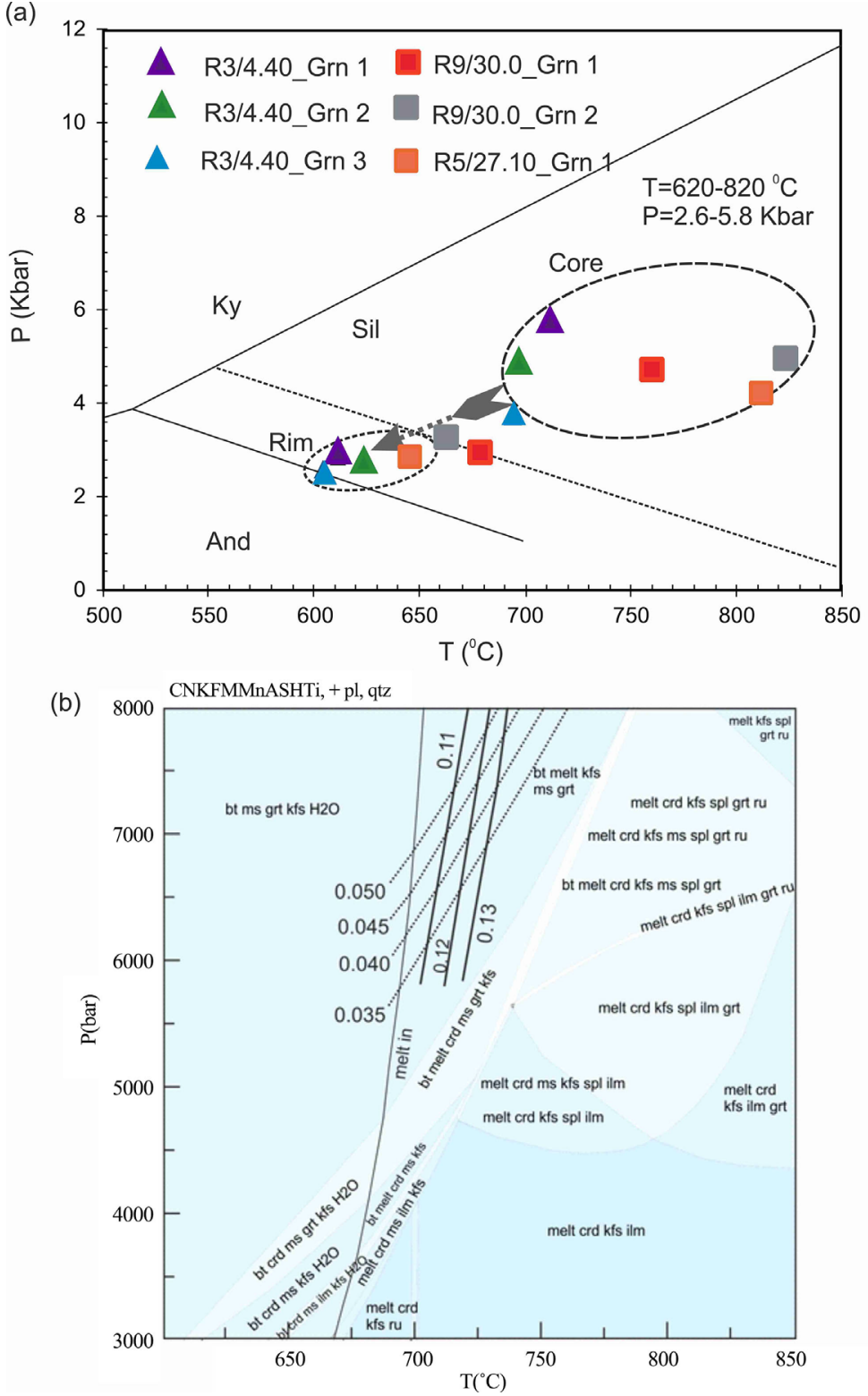

Figure 15. (a) Result of Grn-Bt thermometry and GBPQ barometry for different samples of monazite-bearing dikes. Continuous lines represent the aluminosilicate equilibria of Holdaway \& Mukhopadhyay [62], while the dashed lines are after Pattison [63]; (b) P-T pseudosection showing the crystallization conditions of garnet in the monazite-bearing tonalite dikes. The solid lines are $\mathrm{X}_{\mathrm{Mg}}$ isopleths and the dashed lines are $\mathrm{X}_{\mathrm{Ca}}$ isopleths. The thick lines marked with "core" and "rim" outline the PT conditions for the garnet core and rim for the sample R3/4.40 (Table 5). The used end-member activity models were $\mathrm{Gt}(\mathrm{HP})$, Bio(TCC), Mica(CHA1), melt(HP), Pl(h), San, hCrd, IlGkPy, for the original references see http://www.perplex.ethz.ch/PerpleX_solution_model_glossary.html.

presented in Table 4 and their calculated pseudo-section plot in Figure 15(b). The monazite-bearing sample $\mathrm{R} 3 / 4.40$ defined tonalitic compositions with relatively high abundances of $\mathrm{CaO}, \mathrm{Na}_{2} \mathrm{O}$ and $\mathrm{Al}_{2} \mathrm{O}_{3}$ and dominated by a quartz + $\mathrm{K}$-feldspar + plagioclase + garnet + biotite + monazite assemblage with accessories of thorite and zircon. In this sample garnet core is clearly $\mathrm{Ca}$ and $\mathrm{Mg}$ richer 
than the rim, and the calculated $\mathrm{X}_{\mathrm{Ca}}(0.045-0.050)$ and $\mathrm{X}_{\mathrm{Mg}}(0.12-0.13)$ isopleths demonstrate the pressure and temperature conditions for crystallization at 7 - 8 kbars and $730^{\circ} \mathrm{C}-750^{\circ} \mathrm{C}$ respectively. The rims were crystallized in much lower PT conditions at around $3-4 \mathrm{kbars}$ and $630^{\circ} \mathrm{C}-640^{\circ} \mathrm{C}$. The highest $\mathrm{X}_{\mathrm{Mg}}$ in the analysed garnet grains is $0.16-0.17$; Ca contents in these grains are low, suggesting pressures and temperatures for crystallization around 5 - $6 \mathrm{kbars}$ and $760^{\circ} \mathrm{C}-770^{\circ} \mathrm{C}$. These results are somewhat tentative because the used whole-rock composition does not necessarily represent the effective composition during the garnet growth. However, they indicate a clockwise PT evolution where the cores of some garnet grains crystallized in a relatively high pressure during early stages of melting, then the pressure decreased to the cordierite field during temperature increase and then the rocks cooled down with some uplift.

\section{Discussion}

The monazite-bearing dikes from Kovela granitic complex contain abundant, large monazite grains with zoning textures in BSE images than the monazite grains from the schist zone. Element X-ray mapping and chemical analyses from one representative sample revealed the presence of different zoning patterns varying from weak oscillatory, to sector, to homogeneous rims on dark cores (Figure 3). The concentric zoning pattern may reflect continuous growth during changing conditions in the crystallization environment [64]. The decrease in Th content outward through core zones in some grains (e.g. Figure 3(a) and Figure 3(b)) may reflect fractional crystallization within the equilibration volume of the growing monazite. Concentric zoning observed in BSE images is reflected by their composition as measured by EPMA (Figure 4(a)). Dark zones, predominantly occurring as outer rims and as rare inner cores on some monazite grains (Figures 3(a)-(c)), have lower Th (+Ca and $\mathrm{Si}$ ) and higher Y (+HREE) compared with light zones.

Sector-zoning, is characterized by irregularly shaped, subequant zones with distinct backscattered intensity (composition) associated with embayment, fractures, and inclusions (Figures 3(d)-(f)). It appears that the sector zones texturally overprint on pre-existing primary zones. Catlos [65] and Rubatto [66] also observed sector-zoning in monazite from high-grade metamorphic rocks. Poitrasson [47] suggested that alteration progresses from margin to core and along fractures, and results in depletion of the rare-earth elements (REE, especially light REE) and enrichment of Th. They summarized that changes in composition resulted from selective leaching rather than addition of LREE. This evidence suggests that sector-zoning results from recrystallization during in-situ hydrothermal alteration of pre-existing monazite [67] [68].

The "intergrowth-like" pattern as shown in Figure 3(g) and Figure 3(h)) exhibits internal microstructure similar to the intergrowth of two different minerals. The interlocking of different portions of a monazite with different Th contents suggests that they have crystallized simultaneously. The coexistence of 
monazite grains with different composition in a single sample is well documented [64] [69] [70]. Thus it is considered here that intergrowth of monazites with different compositions is one of the mechanisms for monazite zonation.

The monazite age populations of all Kovela granitic samples studied here show a dominant peak at 1860 - $1840 \mathrm{Ma}$ (Figure 12), similar to monazite ages from similar rocks from West Uusimaa, southern Finland [11]. Based on monazite chemistry coupled with detailed textural analysis can provide a powerful tool to assume that the monazite is formed during the early crystallization of deep-sourced, high-temperature and A-type granitic magma. The Th-rich, Y-poor cores could then have crystallised during melt recrystallization, with the high Th-content being the result of preferential Th incorporation into monazite in a melt-buffered system [33]. Complex zoning observed in monazite requires an adequate understanding of the behaviour of this phase and its chemical and isotopic systems during geological processes. According to Bingen \& van Breemen [36] and Parrish\& Whitehouse [71], monazites preserve older isotopic systematics, surviving high-temperature overprint of $800^{\circ} \mathrm{C}$ or higher and may even record prograde growth ages [72]. Since the peak temperature in the Kovela granitic complex is in a range of $700^{\circ} \mathrm{C}-820^{\circ} \mathrm{C}$, we infer that the obtained ages reflect the peak conditions, because monazites rarely undergo severe lead loss during subsequent geological events [42]. The same conclusion was made for the Archaean granulites in central Finland [73] and for the West Uusimaa area, southern Finland [11].

\section{Conclusions}

Based on petrography, mineral chemistry, whole-rock geochemistry, P-T path calculations and $\mathrm{U}-\mathrm{Pb}$ monazite geochronology for the Kovela granitic complex in the Southern Finland, the following main conclusions can be drawn:

1) The Kovela granitic complex in southern Finland, consist of textural varieties of the porphyritic granites (Grt-bearing, Bt-bearing porphyritic granites and porphyritic potash-feldspar granite) and of multiple monazite-bearing dikes. The monazite-bearing dikes within the main igneous complex are characterized by the highest abundance of monazite, with mineral assemblages includes porphyroblastic garnet and matrix biotite + sillimanite $+\mathrm{K}$-feldspar (microcline) + plagioclase + quartz + chlorite + cordierite.

2) On the basis of the whole-rocks geochemical analyses and mineral chemistry the monazite-bearing dikes plotted in the tonalitic-trondhjemitic field with strong peraluminous and characteristics, whilst Grt-bearing and Bt-bearing porphyritic show moderately peraluminous and calc-alkaline fields.

3) ${ }^{207} \mathrm{~Pb} /{ }^{206} \mathrm{~Pb}$ ages of single monazite grains, combined with their Back-scattered electron (BSE) images are frequently showing age zonation, but there is no systematic change. The younger monazite ages are correlated with higher Th and ${ }^{207} \mathrm{~Pb} /{ }^{206} \mathrm{~Pb}$ ratios, suggesting that multiple growth/ recrystallization of monazite occur in the studied rocks. The age of monazite grain R3/4.4_Mnz 4 is estimated 
at $1796 \pm 16 \mathrm{Ma}$, which is the younger monazite generation. The monazite grain R8/18.50_Mnz 3 represents the maximum age of older growth of monazite as $1912 \pm 28 \mathrm{Ma}$.

4) P-T crystallization condition for the rocks of the studied area records a clockwise P-T path for garnet crystallization at the temperature of $760^{\circ} \mathrm{C}-770^{\circ} \mathrm{C}$ and pressure of 5 - $6 \mathrm{kbar}$. The combination of microstructural observations, petrology, whole-rock geochemistry and geochronology allowed different monazite generations to be related to different magmatic environments. High-temperature strong peraluminous S-type granitic magma derived from deep-sourced materials (upper-mantle to lower-crust, and possible contamination of the upper crust), and is enriched in Th. Therefore, Th-rich monazite could be a typical accessory-mineral indicator of highly peraluminous and tonalitic-trondhjemitic dikes cross-cutting the Kovela granitic complex.

\section{Conflicts of Interest}

The authors declare no conflicts of interest regarding the publication of this paper.

\section{References}

[1] Lehtinen, M., Nurmi, P.A. and Rämö, O.T. (2005) Precambrian Geology of Finland: Key to the Evolution of the Fennoscandian Shield. In: Developments in Precambrian Geology 14, Elsevier, Amsterdam, 736.

[2] Skyttä, P. and Mänttäri, I. (2008) Structural Setting of Late Svecofennian Granites and Pegmatites in Uusimaa Belt, SW Finland: Age Constraints and Implications for Crustal Evolution. Precambrian Research, 164, 86-109. https://doi.org/10.1016/j.precamres.2008.04.001

[3] Huhma, H. (1986) Sm-Nd, U-Pb and Pb-Pb Isotopic Evidence for the Origin of the Early Proterozoic Svecokarelian Crust in Finland. Bulletin 337, Geological Survey of Finland, Espoo, 48.

[4] Haapala, I., Ervamaa, P., Löfgren, A. and Ojaperä, P. (1969) An Occurrence of Monazite in Puumala, Eastern Finland. Bulletin of the Geological Society of Finland, 41, 117-124. https://doi.org/10.17741/bgsf/41.013

[5] Väisänen, M., Mänttäri, I. and Hölttä, P. (2002) Svecofennian Magmatic and Metamorphic Evolution in Southwestern Finland as Revealed by U-Pb Zircon SIMS Geochronology. Precambrian Research, 116, 111-127. https://doi.org/10.1016/S0301-9268(02)00019-0

[6] Ehlers, C., Skiöld, T. and Vaasjoki, M. (2004) Timing of Svecofennian Crustal Growth and Collisional Tectonics in $\mathrm{A}^{\circ}$ Land, SW Finland. Bulletin of the Geological Society of Finland, 76, 63-91. https://doi.org/10.17741/bgsf/76.1-2.004

[7] Suominen, V. (1991) The Chronostratigraphy of South Western Finland with Special Reference to Postjotnian and Subjotnian Diabases. Bulletin of the Geological Society of Finland, 356, 100.

[8] Korsman, K., Korja, T., Pajunen, M. and Virransalo, P. (1999) The GGT/SVEKA Transect: Structure and Evolution of the Continental Crust in the Paleoproterozoic Svecofennian Orogen in Finland. International Geology Review, 41, 287-333. https://doi.org/10.1080/00206819909465144 
[9] Kurhila, M., Vaasjoki, M., Mänttäri, I., Rämö, T. and Nironen, M. (2005) U-Pb Ages and Nd Isotope Characteristics of the Lateorogenic, Migmatizing Microcline Granites in Southwestern Finland. Bulletin of the Geological Society of Finland, 77, 105-128. https://doi.org/10.17741/bgsf/77.2.002

[10] Schreurs, J. and Westra, L. (1986) The Thermotectonic Evolution of a Proterozoic, Low Pressure, Granulite Dome, West Uusimaa, SW Finland. Contributions to Mineralogy and Petrology, 93, 236-250. https://doi.org/10.1007/BF00371326

[11] Mouri, H., Väisänen, M., Huhma, H. and Korsman, K. (2005) Sm-Nd Garnet and $\mathrm{U}-\mathrm{Pb}$ Monazite Dating of High-Grade Metamorphism and Crustal Melting in the West Uusimaa Area, Southern Finland. Geological Society of Sweden (GFF), 127, 123-128. https://doi.org/10.1080/11035890501272123

[12] Ehlers, C., Lindroos, A. and Selonen, O. (1993) The Late Svecofennian Granite-Migmatite Zone of Southern Finland-A Belt of Transgressive Deformation and Granite Emplacement. Precambrian Research, 64, 295-309. https://doi.org/10.1016/0301-9268(93)90083-E

[13] Skyttä, P., Käpyaho, A. and Mänttäri, I. (2005) Supracrustal Rocks in the Kuovila Area, South Western Finland: Structural Evolution, Geochemical Characteristics and the Age of Volcanism. Bulletin of the Geological Society of Finland, 77, 129-150. https://doi.org/10.17741/bgsf/77.2.003

[14] Torvela, T., Mänttäri, I. and Hermansson, T. (2008) Timing of Deformation Phases within the South Finland Shear Zone, SW Finland. Precambrian Research, 160, 277-298. https://doi.org/10.1016/j.precamres.2007.08.002

[15] Väisänen, M. and Skyttä, P. (2007) Late Svecofennian Shear Zones in Southwestern Finland. GFF, 129, 55-64. https://doi.org/10.1080/11035890701291055

[16] Huhma, H., O’Brien, H., Lahaye, Y. and Mänttäri, I. (2011) Isotope Geology and Fennoscandian Lithosphere Evolution. Geological Survey of Finland, Special Paper, 49, 35-48.

[17] Holdaway, M.J. (2000). Application of New Experimental and Garnet Margules Data to the Garnet-Biotite Geothermometer. American Mineralogist, 85, 881-892. https://doi.org/10.2138/am-2000-0701

[18] Bhattacharya, A., Mohanty, L., Maji, A., Sen, S.K. and Raith, M. (1992) Non-Ideal Mixing in the Phlogopite-Annite Boundary: Constraints from Experimental Data on Mg-Fe Partitioning and Reformulation of the Biotite-Garnet Geothermometer. Contributions to Mineralogy and Petrology, 111, 87-93. https://doi.org/10.1007/BF00296580

[19] Hoisch, T.D. (1990) Empirical Calibration of Six Geobarometers for the Mineral Assemblage Quartz + Muscovite + Biotite + Plagioclase + Garnet. Contributions to Mineralogy and Petrology, 104, 225-234. https://doi.org/10.1007/BF00306445

[20] Connolly, J.A.D. (1990) Multivariable Phase Diagrams; an Algorithm Based on Generalized Thermodynamics. American Journal of Science, 290, 666-718. https://doi.org/10.2475/ajs.290.6.666

[21] Connolly, J.A.D. and Petrini, K. (2002) An Automated Strategy for Calculation of Phase Diagram Sections and Retrieval of Rock Properties as a Function of Physical Conditions. Journal of Metamorphic Geology, 20, 697-708. https://doi.org/10.1046/j.1525-1314.2002.00398.x

[22] Connolly, J.A.D. (2005) Computation of Phase Equilibria by Linear Programming; a Tool for Geodynamic Modeling and Its Application to Subduction Zone Decarbonation. Earth and Planetary Science Letters, 236, 524-541. https://doi.org/10.1016/j.epsl.2005.04.033 
[23] Connolly, J.A.D. (2009) The Geodynamic Equation of State: What and How. Geochemistry, Geophysics, Geosystems, 10, 1-19. https://doi.org/10.1029/2009GC002540

[24] Al-Ani, T. and Grönholm, S. (2011) Ore Mineralogy of REE Potential Kovela Th-Granite in Nummi-Pusula, Southern Finland. GTK Research Report 49/2011, 34.

[25] Crowley, J.L., Brown, R.L., Gervais, F. and Gibson, H.D. (2008) Assessing Inheritance of Zircon and Monazite in Granitic Rocks from the Monashee Complex, Canadian Cordillera. Journal of Petrology, 49, 1915-1929. https://doi.org/10.1093/petrology/egn047

[26] Finch, R.J. and Hanchar, J.M. (2003) Structure and Chemistry of Zircon and Zircon-Group Minerals. Reviews in Mineralogy and Geochemistry, 53, 1-25. https://doi.org/10.2113/0530001

[27] Förster, H.J. (2006) Composition and Origin of Intermediate Solid Solutions in the System Thorite-Xenotime-Zircon-Coffinite. Lithos, 88, 35-55. https://doi.org/10.1016/j.lithos.2005.08.003

[28] Clarke, G.L., White, R.W., LUI, S., Fitz Herbert, J.A. and Pearson, N.J. (2006) Contrasting Behaviour of Rare Earth and Major Elements during Partial Melting in Granulite Facies Migmatites, Wuluma Hills, Arunta Block, Central Australia. Journal of Metamorphic Geology, 25, 1-18. https://doi.org/10.1111/j.1525-1314.2006.00673.x

[29] Gasser, D., Bruand, E., Rubatto, D. and Stüwe, K. (2012) The Behaviour of Monazite from Greenschist Facies Phyllites to Anatectic Gneisses: An Example from the Chugach Metamorphic Complex, Southern Alaska. Lithos, 134, 108-122. https://doi.org/10.1016/j.lithos.2011.12.003

[30] Wing, B.A., Ferry, J.M. and Harrison, T.M. (2003) Prograde Destruction and Formation of Monazite and Allanite during Contact and Regional Metamorphism of Pelites: Petrology and Geochronology. Contributions to Mineralogy and Petrology, 145, 228-250. https://doi.org/10.1007/s00410-003-0446-1

[31] Terry, M.P., Robinson, P., Hamilton, M.A. and Jercinovic, M.J. (2000) Monazite Geochronology of UHP and HP Metamorphism, Deformation, and Exhumation, Nordoyane, Western Gneiss Region, Norway. American Mineralogist, 85, 1651-1664. https://doi.org/10.2138/am-2000-11-1208

[32] Cocherie, E., Mezeme, B., Legendre, O., Fanning, C.M., Faure, M. and Rossi, P. (2005) Electron-Microprobe Dating as a Tool for Determining the Closure of Th-U-Pb Systems in Migmatitic Monazites. American Mineralogist, 90, 607-618. https://doi.org/10.2138/am.2005.1303

[33] Kohn, M., Wieland, M.S., Parkinson, C.D. and Upreti, B.N. (2005) Five Generations of Monazite in Langtang Gneisses: Implications for Chronology of the Himalayan Metamorphic Core. Journal of Metamorphic Geology, 23, 399-406. https://doi.org/10.1111/j.1525-1314.2005.00584.x

[34] Pyle, J., Spear, F., Rudnick, R. and McDonough, W. (2001) Monazite-Xenotime Garnet Equilibrium in Metapelites and a New Monazite-Garnet Thermometer. Journal of Petrology, 42, 2083-2107. https://doi.org/10.1093/petrology/42.11.2083

[35] Finger, F. and Krenn, E. (2007) Three Metamorphic Monazite Generations in a High-Pressure Rock from the Bohemian Massif and the Potentially Important Role of Apatite in Stimulating Polyphase Monazite Growth along a PT Loop. Lithos, 95, 103-115. https://doi.org/10.1016/j.lithos.2006.06.003

[36] Bingen, B. and van Breemen, O. (1998) U-Pb Monazite Ages in Amphibolite to 
Granulite-Facies Orthogneiss Reflect Hydrous Mineral Breakdown Reactions: Sveconorwegian Province of SW Norway. Contributions to Mineralogy and Petrology, 85, 141-148. https://doi.org/10.1007/s004100050428

[37] Harlov, D.E. and Förster, H.J. (2002) High-Grade Fluid Metasomatism on Both Local and a Regional Scale: The Seward Peninsula, Alaska, and the Val Strona di Omegna, Ivrea-Verbano Zone, Northern Italy. Part II: Phosphate Mineral Chemistry. Journal of Petrology, 43, 801-824. https://doi.org/10.1093/petrology/43.5.801

[38] Zhu, X.K. and O’Nions, R.K. (1999) Monazite Chemical Composition: Some Implications for Monazite Geochronology. Contributions to Mineralogy and Petrology, 137, 351-363. https://doi.org/10.1007/s004100050555

[39] Broska, I., Petrík, I. and Williams, C.T. (2000) Coexisting Monazite and Allanite in Peraluminous Granitoids of the Tribeč Mountains, Western Carpathians. American Mineralogist, 85, 22-32. https://doi.org/10.2138/am-2000-0104

[40] Hoshino, M., Watanabe, Y. and Ishihara, S. (2012) Crystal Chemistry of Monazite from Granitic Rocks of Japan: Petrology Implications. Canadian Mineralogist, 50, 1331-1346. https://doi.org/10.3749/canmin.50.5.1331

[41] Berger, A., Gnos, E., Janots, E., Fernandez, A. and Giese, J. (2008) Formation and Composition of Rhabdophane, Bastnäsite and Hydrated Thorium Minerals during Alteration: Implications for Geochronology and Low Temperature Processes. Chemical Geology, 254, 238-248. https://doi.org/10.1016/j.chemgeo.2008.03.006

[42] Föster, G., Kinny, P., Vance, D., Prince, C. and Harris, N. (2000) The Significance of Monazite U-Th-Pb Age Data in Metamorphic Assemblages; a Combined Study of Monazite and Garnet Chronometry. Earth and Planetary Science Letters, 181, 327-340. https://doi.org/10.1016/S0012-821X(00)00212-0

[43] Föster, G., Gibson, H.D., Parrish, R., Horstwood, M., Fraser, J. and Tindle, A. (2002) Textural, Chemical and Isotopic Insights into the Nature and Behaviour of Metamorphic Monazite. Chemical Geology, 191, 183-207. https://doi.org/10.1016/S0009-2541(02)00156-0

[44] Cuney, M. and Friedrich, M. (1987) Physicochemical and Crystal-Chemical Controls on Accessory Mineral Paragenesis in Granitoids: Implications for Uranium Metallogenesis. Bulletin de Mineralogie, 110, 235-247. https://doi.org/10.3406/bulmi.1987.7983

[45] Broska, I. and Petrik, I. (2008) Genesis and Stability of Accessory Phosphates in Silicic Magmatic Rocks: A Western Carpathian Case Study. Mineralogia, 39, 53-65. https://doi.org/10.2478/v10002-008-0004-6

[46] Linthout, K. (2007) Tripartite Division of the System $2 \mathrm{REEPO}_{4}-\mathrm{CaTh}\left(\mathrm{PO}_{4}\right)_{2}-2 \mathrm{ThSiO}_{4}$, Discreditation of Brabantite, and Recognition of Cheralite as the Name for Members Dominated by CaTh $\left(\mathrm{PO}_{4}\right)_{2}$. Canadian Mineralogist, 45, 503-508. https://doi.org/10.2113/gscanmin.45.3.503

[47] Poitrasson, F., Chenery, S. and Bland, D.J. (1996) Contrasted Monazite Hydrothermal Alteration Mechanisms and Their Geochemical Implications. Earth and Planetary Science Letters, 145, 79-96. https://doi.org/10.1016/S0012-821X(96)00193-8

[48] Van Emden, R., Thornber, M.R. and Lincoln, F.J. (1997) The Incorporation of Actinides in Monazite and Xenotime from Placer Deposits in Western Australia. Canadian Mineralogist, 35, 95-104.

[49] Harlov, D., Wirth, R. and Hetherington, C. (2007) The Relative Stability of Monazite and Huttonite at $300-900^{\circ} \mathrm{C}$ and $200-1000 \mathrm{MPa}$ : Metasomatism and the Propagation of Metastable Mineral Phases. American Mineralogist, 92, 1652-1664. https://doi.org/10.2138/am.2007.2459 
[50] Lisowiec, K., Budzyń, B., Słaby, E., Renno, A.D. and Götze, J. (2012) Fluid-Induced Magmatic and Post-Magmatic Zircon and Monazite Patterns in Granitoid Pluton and Related Rhyolitic Bodies. Chemie der Erde-Geochemistry, 73, 163-179. https://doi.org/10.1016/j.chemer.2012.07.005

[51] Maniar, P.D. and Piccoli, P.M. (1989) Tectonic Discrimination of Granitoids. Geological Society of America Bulletin, 101, 635-643. https://doi.org/10.1130/0016-7606(1989)101<0635:TDOG>2.3.CO;2

[52] O’Connor, J.T. (1965) A Classification for Quartz-Rich Igneous Rocks Based on Feldspar Ratios. U.S. Geol. Surv. Prof. Pap., 525-B, 79-84.

[53] Barker, F. and Arth, J.G. (1976) Generation of Trondhjemite-Tonalite Liquids and Archaean Bimodal Trondhjemite-Basalt Suites. Geology, 4, 596-600. https://doi.org/10.1130/0091-7613(1976)4<596:GOTLAA >2.0.CO;2

[54] Boynton, W.V. (1984) Geochemistry of the Rare Earth Elements: Meteorite Studies. In: Henderson, P., Ed., Rare Earth Element Geochemistry, Elsevier, Amsterdam, 63-114. https://doi.org/10.1016/B978-0-444-42148-7.50008-3

[55] Ludwig, K.R. (2003) Isoplot/EX, Version 3. A Geochronological Toolkit for Microsoft Excel. Berkeley Geochronology Center, Berkeley, Special Publication No. 4, 70.

[56] Stern, R.A. and Berman, R.G. (2000) Monazite U-Pb and Th-Pb Geochronology by Ion Microprobe, with an Application to in Situ Dating of an Archean Metasedimentary Rocks. Chemical Geology, 172, 113-130. https://doi.org/10.1016/S0009-2541(00)00239-4

[57] Wu, C.M., Zhang, J. and Ren, L.D. (2004) Empirical Garnet-Biotite-Plagioclase-Quartz (GBPQ) Geobarometry in Medium- to High-Grade Metapelites. Journal of Petrology, 45, 1907-1921. https://doi.org/10.1093/petrology/egh038

[58] Holdaway, M.J. (2001) Recalibration of the GASP Geobarometer in Light of Recent Garnet and Plagioclase Activity Models and Versions of the Garnet-Biotite Geothermometer. American Mineralogist, 86, 1117-1129. https://doi.org/10.2138/am-2001-1001

[59] Connolly, J.A.D. (2005) Computation of Phase Equilibria by Linear Programming: A Tool for Geodynamic Modeling and Its Application to Subduction Zone Decarbonation. Earth and Planetary Science Letters, 236, 524-541. https://doi.org/10.1016/j.epsl.2005.04.033

[60] Connolly, J.A.D. and Thompson, A.B. (1989) Fluid and Enthalpy Production during Regional Metamorphism. Contributions to Mineralogy and Petrology, 102, 347-366. https://doi.org/10.1007/BF00373728

[61] Holland, T.J.B. and Powell, R. (2011) An Improved and Extended Internally Consistent Thermodynamic Dataset for Phases of Petrological Interest, Involving a New Equation of State for Solids. Journal of Metamorphic Geology, 29, 333-383. https://doi.org/10.1111/j.1525-1314.2010.00923.x

[62] Holdaway, M.J. and Mukhopadhyay, B. (1993) A Re-Evaluation of the Stability Relations of Andalusite: Thermochemical Data and Phase Diagram for the Alumino Silicates. American Mineralogist, 78, 298-315.

[63] Pattison, D.R.M. (1992) Stability of Andalusite and Sillimanite and the $\mathrm{Al}_{2} \mathrm{SiO}_{5}$ Triplepoint: Constraints from the Ballachulish Aureole, Scotland. Journal of Geology, 100, 423-446. https://doi.org/10.1086/629596

[64] Zhu, X.K. and O’Nions, R.K. (1999) Zonation of Monazite in Metamorphic Rocks and Its Implications for High Temperature Thermochronology: A Case Study from the Lewisian Terrain. Earth and Planetary Science Letters, 171, 209-220. https://doi.org/10.1016/S0012-821X(99)00146-6 
[65] Catlos, E.J., Harrison, T.M., Manning, C.E., Grove, M., Rai, S.M., Hubbard, M.S. and Upreti, B.N. (2002) Records of the Evolution of the Himalayan Orogen from in Situ Th-Pb Ion Microprobe Dating of Monazite: Eastern Nepal and Garhwal. Journal of Asian Earth Sciences, 20, 459-479. https://doi.org/10.1016/S1367-9120(01)00039-6

[66] Rubatto, D., Hermann, J. and Buick, I.S. (2006) Temperature and Bulk Composition Control on the Growth of Monazite and Zircon during Low-Pressure Anatexis (Mount Stafford, Central Australia). Journal of Petrology, 47, 1973-1996. https://doi.org/10.1093/petrology/egl033

[67] Ayers, J.C., Miller, C.F., Gorisch, B. and Milleman, J. (1999) Textural Development of Monazite during High-Grade Metamorphism: Hydrothermal Growth Kinetics, with Implications for U-Th-Pb Geochronology. American Mineralogist, 84, 1766-1780. https://doi.org/10.2138/am-1999-11-1206

[68] Townsend, K.J., Miller, C.F., D’Andrea, J.L., Ayers, J.C., Harrison, T.M. and Coath, C.D. (2000) Low Temperature Replacement of Monazite in the Ireteba Granite, Southern Nevada; Geochronological Implications. Chemical Geology, 172, 95-112. https://doi.org/10.1016/S0009-2541(00)00238-2

[69] Faure, M., Mezeme, E.B., Cocherie, A., Rossi, P., Chemenda, A. and Boutelier, D. (2008) Devonian Geodynamic Evolution of the Variscan Belt, Insights from the French Massif Central and Massif Armoricain. Tectonics, 27, 1-19. https://doi.org/10.1029/2007TC002115

[70] Chen, C.-H., Liu, Y.-H., Lee, C.-Y., Xiang, H. and Zhou, H.-W. (2012) Geochronology of Granulite, Charnockite and Gneiss in the Poly-Metamorphosed Gaozhou Complex (Yunkai Massif), South China: Emphasis on the In-Situ EMP Monazite Dating. Lithos, 144, 109-129. https://doi.org/10.1016/j.lithos.2012.04.009

[71] Parrish, R. and Whitehouse, M. (1999) Constraints on the Diffusivity of $\mathrm{Pb}$ in Monazite, Its Closure Temperature, and Its U-Th-Pb Systematics in Metamorphic Terrains, from a TIMS and SIMS Study. 10 th Meeting of European Union of Geosciences, Strasbourg, 28 March-1 April 1999, 711.

[72] Vry, J., Compston, W. and Cartwright, I. (1996) SHRIMP II Dating of Zircons and Monazites: Reassessing the Timing of High-Grade Metamorphism and Fluid Flow in the Reynold Range, Northern Arunta Block, Australia. Journal of Metamorphic Geology, 14, 335-350. https://doi.org/10.1111/j.1525-1314.1996.00335.x

[73] Hölttä, P., Huhma, H., Mänttäri, I. and Paavola, J. (2000) P-T-T Development of Archaean Granulites in Varpaisjärvi, Central Finland. II. Dating of High-Grade Metamorphism with the U-Pb and Sm-Nd Methods. Lithos, 50, 121-136. https://doi.org/10.1016/S0024-4937(99)00055-9

\section{Appendix 1}

https://drive.google.com/file/d/1KeGevj-gXsnIXwxOdB3SD0qTV2aUL89n/view ?usplu003dsharing_eid $\backslash u 0026 t s \backslash u 003 d 5 d 0365 b e$ 